\title{
Working
}

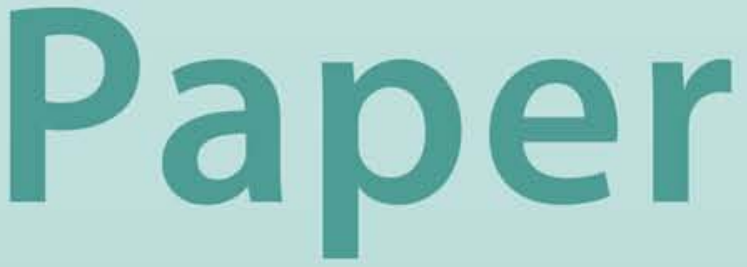




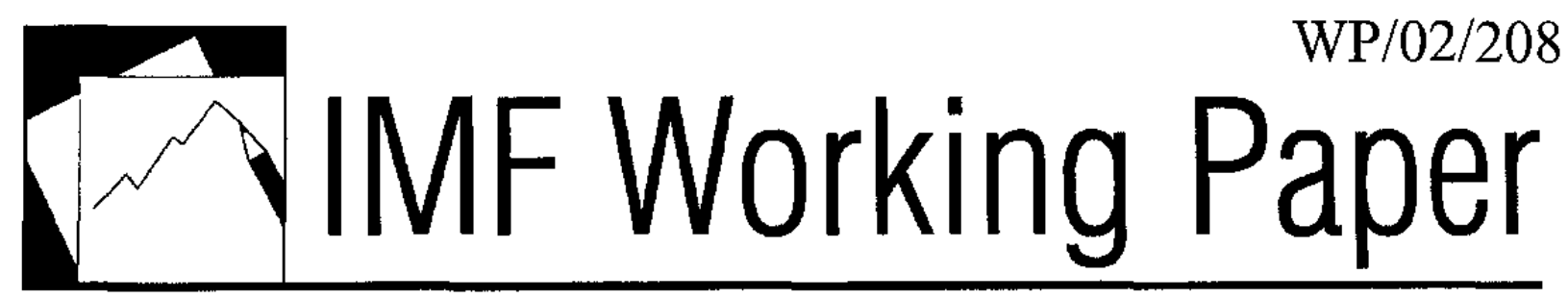

The Effectiveness of Fiscal Policy in Stimulating Economic Activity-A

Review of the Literature

Richard Hemming, Michael Kell, and

Selma Mahfouz 


\title{
IMF Working Paper
}

Fiscal Affairs Department

\section{The Effectiveness of Fiscal Policy in Stimulating Economic Activity-A Review of the Literature 1}

\author{
Prepared by Richard Hemming, Michael Kell, and Selma Mahfouz ${ }^{2}$
}

December 2002

\begin{abstract}
The views expressed in this Working Paper are those of the author(s) and do not necessarily represent those of the IMF or IMF policy. Working Papers describe research in progress by the author(s) and are published to elicit comments and to further debate.
\end{abstract}

This paper reviews the theoretical and empirical literature on the effectiveness of fiscal policy. The focus is on the size of fiscal multipliers, and on the possibility that multipliers can turn negative (i.e., that fiscal contractions can be expansionary). The paper concludes that fiscal multipliers are overwhelmingly positive but small. However, there is some evidence of negative fiscal multipliers.

JEL Classification Numbers:E62, H30

Keywords: Fiscal policy, economic activity, fiscal multipliers

Author’s E-Mail Address: rhemming@imf.org

\footnotetext{
${ }^{1}$ This is an updated version of a paper that has been in circulation since mid-2000. It incorporates comments from many colleagues, but the authors wish to acknowledge in particular the contributions of Anthony Annett, Nigel Chalk, and Steven Symansky.

${ }^{2}$ Michael Kell works in the Office of the Deputy Prime Minister, United Kingdom, and Sclma Mahfouz in the Ministère des Finances, France.
} 


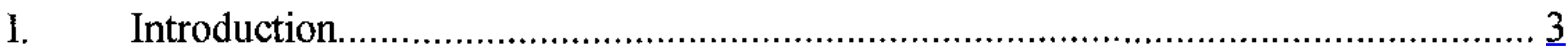

II. The Theoretical Literature .......................................................................... $\underline{3}$

A. Demand-Side Effects of Fiscal Policy .................................................... 4

B. Supply-Side Effects of Fiscal Policy ….................................................. 9

C. Institutional Aspects of Fiscal Policy ............................................. 10

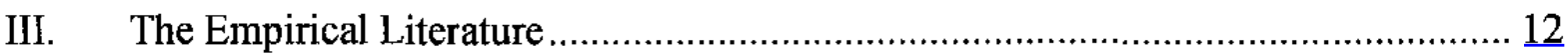

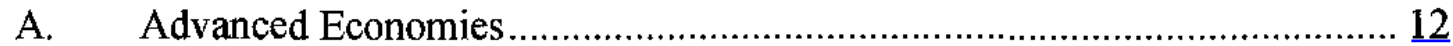

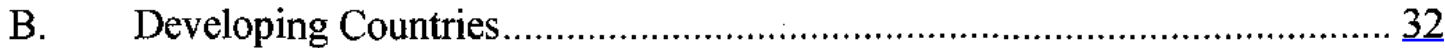

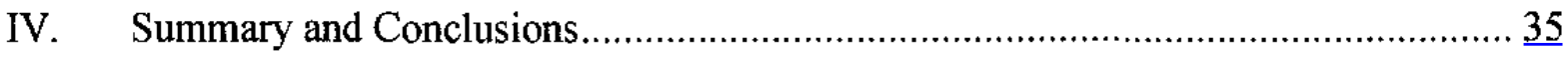

Tables

1. Estimates of Multipliers from Macromodel Simulations...................................... 14

2. Government Expenditure Multipliers in Large European Countries ...................... 15

3. Effects of Fiscal Policy on Output (VAR Estimates) .................................... 20

4. Cross-Section Studies of Expansionary Fiscal Contractions .............................. 23

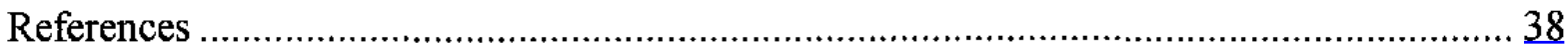




\section{INTRODUCTION}

During the 1980s and much of the1990s, discussions of fiscal policy focused mainly on high fiscal deficits and government debt as a source of inflation and balance of payments problems, and on the contribution of fiscal adjustment to stabilization programs designed to address such problems. Attention was also paid to the way in which well-designed tax systems and spending programs could foster sustainable longer-term growth. However, with the prolonged slump in Japan, the severe recessions in Indonesia, Korea, and Thailand during the Asian crisis, and the more recent downturns in the United States and Europe, emphasis has shifted to the role expansionary fiscal policy can play in stimulating economic activity. ${ }^{3}$

The Keynesian view that fiscal expansions are beneficial in this regard has been the subject of long-standing debate about both its theoretical validity and its practical importance. Indeed, the 1990 s have seen the emergence of a view that contractionary fiscal policy, rather than having the often assumed contractionary short-term impact on output, could be expansionary. Examples of expansionary fiscal contractions from Europe, most notably Denmark and Ireland, have been cited to illustrate such an outcome (in the first instance by Giavazzi and Pagano, 1990). An expansionary fiscal contraction nevertheless contradicts a widely held belief among macroeconomists that fiscal multipliers, although they might be small, are nonetheless positive. This paper assesses whether this is a reasonable belief, and therefore whether the recent emphasis placed on traditional countercyclical fiscal policy is justified.

The paper is organized as follows. Section II briefly reviews the theoretical literature in an attempt to identify the factors that in principle determine whether short-term fiscal multipliers are large or small, and the circumstances under which they become negative. ${ }^{4}$ Section III then reviews at greater length the empirical literature, to see what in practice determines the size and sign of fiscal multipliers. Section IV contains a summary and conclusions.

\section{ThE THEORETICAL Literature}

This section describes the various influences on the multiplier effects of government spending increases and tax cuts. The intention is to identify the circumstances under which fiscal expansions will tend to be relatively effective or relatively ineffective in stimulating economic activity (i.e., whether fiscal multipliers are fairly large or fairly small, but still

\footnotetext{
${ }^{3}$ Throughout this paper, the terms economic activity, output, and growth are used interchangeably when discussing the short-term impact of fiscal policy.

${ }^{4}$ The term fiscal multipliers is used as a general indicator of the impact of fiscal expansions and contractions on output.
} 
positive), and to highlight in particular when fiscal contractions might be expansionary (i.e., whether fiscal multipliers are negative).

\section{A. Demand-Side Effects of Fiscal Policy}

\section{The Keynesian approach and crowding out}

A natural place to start a review of the theoretical literature is with the Keynesian approach. The simplest Keynesian model assumes price rigidity and excess capacity, so that output is determined by aggregate demand. In this model, a fiscal expansion has a multiplier effect on aggregate demand and output. The Keynesian multiplier exceeds one, it increases with the responsiveness of consumption to current income, and it is larger for a spending increase than for a tax cut. ${ }^{5}$ If a spending increase is matched by a tax increase, the resulting "balanced budget multiplier" is exactly one.

Extensions of the simplest Keynesian model allow for crowding out through induced changes in interest rates and the exchange rate. This is additional to direct crowding out which occurs to the extent that the government provides goods and services that substitute for those provided by the private sector, and insofar as part of any increase in domestic demand in an open economy is met from imports. The extent of crowding out affects the size of fiscal multipliers but does not change their sign. In the standard IS-LM model, private investment depends negatively on interest rates, and therefore a fiscal expansion paid for by increased borrowing that leads to higher interest rates reduces investment. ${ }^{6}$ In the open economy IS-LM (Mundell-Fleming) model, there can also be crowding out through the exchange rate. Higher interest rates attract capital inflows which appreciate the exchange rate, and the resulting deterioration in the external current account offsets the increase in domestic demand deriving from a fiscal expansion.

Crowding out through interest rates and the exchange rate is influenced by certain features of the IS-LM framework.

- The determinants of private investment. Crowding out is jikely to be greater if investment is fairly sensitive to interest rates. However, if investment is an increasing function of current income, multiplier-accelerator models can generate quite large fiscal multipliers even if there is crowding out through interest rates.

- Money demand and monetary policy. Crowding out through interest rates hinges on the assumption that money demand is a function of interest rates and income. The less

\footnotetext{
${ }^{5}$ The multiplier is smaller for proportional income (and consumption) taxes than for lump-sum taxes. When there are both lump-sum and proportional taxes, the multiplier effect of changes in either type of tax is the same as for proportional taxes alone.

${ }^{6}$ In fact any item of interest-sensitive spending (e.g., purchases of consumer durables or housing services) could be affected, but the largest impact will likely be on investment.
} 
sensitive money demand is to interest rates, and the more sensitive it is to income, the more crowding out there will be. However, the tendency for interest rates to rise in response to a fiscal expansion could be offset by an easing of monetary policy. ${ }^{7}$

- Openness and the exchange rate regime. In an open economy, the size of fiscal multipliers will depend primarily on whether the exchange rate is flexible or fixed. With a flexible exchange rate, capital inflows attracted by higher domestic interest rates appreciate the exchange rate. ${ }^{8}$ With perfect capital mobility, there is complete crowding out and so fiscal policy is ineffective. ${ }^{9,10}$ With a fixed exchange rate, a fiscal expansion will produce a smaller increase in interest rates than in a closed economy, and with perfect capital mobility fiscal policy is very effective because the money supply will increase to ensure that domestic interest rates will not rise at all (i.e., domestic and foreign interest rates will remain the same). ${ }^{11}$

The extent of crowding out is also affected by price flexibility. Neo Keynesian models allow for price flexibility, although nominal rigidities remain if prices do not adjust completely to clear markets. ${ }^{12}$ Price flexibility, even if it is limited in the short term, will tend to narrow the range of values taken by fiscal multipliers, and in particular to limit the influence of the exchange rate regime. In a closed economy, a fiscal expansion will lead to higher prices that choke off part of the increase in aggregate demand in the short term, reinforcing the crowding out through interest rates that occurs with price rigidity. In an open economy with a flexible exchange rate, the extent of crowding depends on the response of domestic prices to changes in the exchange rate. In particular, if domestic prices move with the exchange rate, crowding out will be less than with price rigidity, since appreciation of the exchange rate will lower prices. With a fixed exchange rate, the current account will deteriorate in response to price increases via a real appreciation of the exchange rate, and there will be more crowding out than with price rigidity.

\footnotetext{
${ }^{7}$ Unless the demand for money is infinitely sensitive to interest rates, and there is a liquidity trap, in which case monetary policy is ineffective and fiscal policy is the only available policy instrument.

${ }^{8}$ This assumes that foreign exchange reserves are unchanged. If the fiscal expansion is financed by drawing down reserves, the resulting monetary expansion reduces crowding out.

${ }^{9}$ If there is a flexible exchange rate but capital is not mobile, the fiscal multiplier is the same as in a closed economy.

${ }^{10}$ Fiscal policy may have an impact, however, through revaluation effects of exchange rate changes.

${ }^{11}$ The implications of openness and the exchange rate regime for the effectiveness of monetary policy are the exact opposite. With a fixed exchange rate, capital outflows make monetary policy ineffective by offsetting an interest rate reduction, while with a flexible exchange rate monetary policy has a powerful influence because an interest rate reduction is bolstered by exchange rate depreciation.

${ }^{12}$ As can be the case if price adjustment is costly (i.e., there are so-called menu costs) and therefore infrequent (Mankiw, 1985), or price and wage adjustments are staggered across the economy (Taylor, 1979).
} 
Changes in interest rates, the exchange rate, and prices can in addition influence crowding out via wealth effects on aggregate demand. ${ }^{13}$ This will be the case in particular if consumption depends on current financial wealth. ${ }^{14}$ An increase in interest rates will generally reduce the nominal value of financial assets, as will an appreciation of the exchange rate in the case of foreign currency assets. For households and firms that are net creditors, these wealth effects will reinforce crowding out effects through interest rates and exchange rates described above, and reduce fiscal multipliers further. ${ }^{15}$ The impact of higher prices is more ambiguous, since they can have opposite effects on nominal and real wealth.

Finally, dynamic effects of fiscal policy have to be considered (Auerbach and Kotlikoff, 1987). If crowding out takes longer to manifest itself than the direct impact effect of a fiscal expansion, fiscal multipliers are likely to be relatively large in the short term but then to decline over time. In particular, the wage-price loop, which determines the rapidity of price increases in response to a fiscal expansion, and the responsiveness of trade volumes to changes in the domestic currency price of imports and exports, will influence the size of short-term fiscal multipliers.

\section{Non-Keynesian effects of fiscal policy}

Non-Keynesian effects of fiscal policy emerge from new classical models which address well-known shortcomings of the Keynesian approach, and in particular its lack of microeconomic foundations. While new classical models place considerable emphasis on the supply-side effects of fiscal policy, the focus here is on features of some new classical models with demand-side implications.

Rational expectations. Although some variants of the Keynesian approach recognize the role of expectations (e.g., on consumption in life cycle and permanent income models), they typically rely on adaptive expectations. By comparison, rational expectations tend to bring forward adjustments in variables that would occur more progressively with adaptive expectations. Thus the longer-term effects of fiscal policy will matter even in the short term, and in this connection the distinction between temporary and permanent policy changes is important. For example, while a temporary fiscal expansion that has no long-term effects will not influence expectations, a permanent fiscal expansion can add to crowding out-possibly to an extent that fiscal multipliers turn negative-because households and firms will expect that an initial increase in interest rates and appreciation of the exchange rate will persist and could become larger (Krugman and Obstfeld, 1997).

\footnotetext{
${ }^{13}$ These effects are often referred to as Pigou effects or real balance effects.

14 The case where consumers are forward-looking and consumption depends not only on current financial wealth, but also on anticipated lifetime human and financial wealth, is discussed below.

${ }^{15}$ However, if the government's domestic debt is mostly floating-rate bonds, wealth effects will be very limited since interest rate changes should not affect the nominal value of such bonds.
} 
Ricardian equivalence. The Keynesian approach is based on an assumption that consumption is related to current income. If consumers are Ricardian in the sense that they are forward-looking, and are fully aware of the government's intertemporal budget constraint, they will anticipate that a tax cut today, financed by issuing government debt, will result in higher taxes being imposed on their infinitely lived families in the future. Permanent income is therefore unaffected, and in the absence of liquidity constraints and with perfect capital markets, consumption will not change (Barro, 1974). Thus there is Ricardian equivalence between taxes and debt. Perfect Ricardian equivalence implies that a reduction in government saving resulting from a tax cut is fully offset by higher private saving, and aggregate demand is not affected. The fiscal multiplier is zero in this case.

The focus in the Ricardian equivalence literature is on the effects of cuts in lump-sum taxes for a given path of government spending. With proportional or progressive taxes, the way in which the supply-side effects of tax cuts affect permanent income also have to be taken into account. If a fiscal expansion takes the form of increased government spending, the impact on permanent income depends on how this will be paid for in the future. A temporary increase in government spending that will be offset by cuts in future spending will have no impact. However, an increase in government spending financed by higher future taxes will lead to a reduction in permanent income and consumption — and therefore possibly negative fiscal multipliers - although the precise extent of the resulting fall in output will depend on the productivity of government spending.

It is important to note that Ricardian equivalence is based on strong assumptions. Thus short time horizons, less than perfect foresight, partial liquidity constraints, imperfect capital markets, and a nonaltruistic desire to pass some of the current fiscal burden to future generations can reestablish a stronger link between fiscal policy and consumption (Mankiw and Summers, 1984; and Blanchard, 1985). Consequently, the practical significance of Ricardian equivalence is problematic, at least in its perfect form.

It is nevertheless worth asking whether there are circumstances where a Ricardian response is more likely. For example, if a government is bound by a fiscal rule which requires that a fiscal expansion has to be reversed, then even individuals who do not have very long time horizons may adjust their saving behavior to at least partially prepare for higher future taxes. ${ }^{16}$ Similarly, where it is widely perceived that the current path of government debt is unsustainable, and that future tax increases will soon be required to lower the debt, there could be a seemingly Ricardian offset to a fiscal expansion even in a Keynesian framework (Sutherland, 1997). However, if forward-looking individuals fear that debt will be monetized, or that private savings will be preempted by the government, fiscal policy could be seemingly Keynesian in effect in a Ricardian framework, especially once debt or spending exceeds certain threshold levels (Bertola and Drazen, 1993).

\footnotetext{
${ }^{16}$ For a discussion in the context of the Maastricht rules, see Cotis and others (1998).
} 
Consumption smoothing. Ricardian behavior results in consumption smoothing to offset the lifetime and intergenerational redistribution implied by government debt policy. Overlapping generations models also produce consumption smoothing, but with no bequest motive this occurs over an individual's lifetime. However, a criticism of both the infinitely lived families and overlapping generations models is that they cannot satisfactorily explain the more realistic case of partial consumption smoothing. Thus Mankiw (2000) develops a saversspenders model in which not only is consumption smoothing less than perfect, but also many people have little net worth and bequests are an important influence on wealth accumulation (which are observed facts).

Interest rate premia and credibility. Risk premia on interest rates are an important channel through which debt accumulation may affect the fiscal multiplier. As government debt builds up with fiscal expansion(s), risk premia that reflect the mounting risk of default or increasing inflation risk will reinforce crowding out effects through interest rates (Miller, Skidelsky, and Weller, 1990). Under such circumstances, a temporary fiscal expansion will be more effective than a permanent one, because it poses less risk of undermining debt sustainability. ${ }^{17}$ In this context, policy credibility is crucial. If there is little faith in the government's ability to reverse a temporary spending increase or tax cut because it lacks a track record of fiscal prudence, and the expectation is that a fiscal expansion which is announced to be temporary will in fact turn out to be permanent, then interest rates will most likely incorporate risk premia. Sizable risk premia represent perhaps the clearest reason that fiscal multipliers could turn negative, because private spending responds positively to a credible commitment to debt reduction and a lowering of risk premia. This is one of the main explanations for expansionary fiscal contractions given by Giavazzi and Pagano (1990) and Alesina and Perotti (1997).

Uncertainty. If a fiscal expansion is associated with increased uncertainty, precautionary behavior on the part of households and firms can also reduce fiscal multipliers and possibly turn them negative. In particular, households may accumulate precautionary savings and firms may delay irreversible investments (Caballero and Pyndick, 1996). ${ }^{18}$ More generally, in an uncertain environment confidence effects are likely to be important. While the theoretical underpinning of confidence effects that are not related to expectations or credibility is unclear, the general idea is that consumption or investment may depend on households' or firms' attitudes to the general economic environment, and their confidence in this regard is influenced by government policies (e.g., anticipated future deficits have a negative effect on confidence).

\footnotetext{
${ }^{17}$ In an open economy with highly mobile capital, fiscal expansion(s) that are a risk to debt sustainability can also raise fears of future balance of payments problems, and thus lead to an immediate reduction in foreign investment and to capital outflows with adverse consequences for economic activity.

${ }^{18}$ Capital flows are another channel through which uncertainty can affect fiscal multipliers.
} 


\section{B. Supply-Side Effects of Fiscal Policy}

The analysis of the stabilization role of fiscal policy traditionally focuses on its demand-side effects, while supply-side effects are seen as more important over the longer term. However, the distinction between short-term demand-side concerns and longer-term supply-side issues may not be so clear. If the economy is operating at full capacity and productive capacity cannot be increased in the short term, a fiscal expansion (which may be undertaken on the mistaken assumption that there is excess capacity or for political reasons) has to be crowded out. ${ }^{19}$ Only policies that promote supply-side responses can address capacity constraints, and their impact is primarily longer term. However, supply-side effects of fiscal policy can have short-term demand-side consequences because of expectations that longer-term growth will be higher. If a fiscal expansion is imparted through tax cuts and spending increases that are good for the supply side, this will tend to increase fiscal multipliers.

Taxes, government spending, and growth. In assessing the short-term impact of fiscal policy, attention should thus be paid to the way in which changes to labor income taxes affect the supply of labor and changes to capital taxes affect saving and investment. ${ }^{20}$ The location of internationally mobile labor and capital can also be affected. In the final analysis, however, the impact of tax changes on the supply of labor and capital, and thus on growth, is an empirical issue about which clear-cut conclusions have yet to be provided. ${ }^{21}$ Attention should also be paid to the way in which spending changes affect the productivity of labor and capital. In particular, government spending on public goods and other goods with positive externalities - and by the same token reductions in spending which is wasteful because it does not share such characteristics-can lead to higher growth. This is demonstrated in models where the government invests in both physical and human capital (Murphy, Shleifer, and Vishny, 1989; and Lucas, 1988). Other models show that such investment can move the economy between bad and good equilibria (Azariadis and Drazen, 1990), with large macroeconomic differences (e.g., as the economy escapes a development trap) which imply that fiscal multipliers are very large.

Some attention has also been paid to the way in which labor market characteristics might influence whether changes in taxes and spending can have non-Keynesian effects through supply-side channels. In particular, Alesina and Perotti (1997) note that increases in labor income taxes can have a significant negative supply-side impact in unionized, imperfectly competitive labor markets where before-tax wages, and hence labor costs, also increase to reflect the higher taxes. However, they argue that an agreement on wage moderation with trade unions could limit the increase in before-tax wages, or inflationary pressures during a fiscal contraction accompanied by a sharp devaluation, thus reducing the fiscal multiplier and

\footnotetext{
${ }^{19}$ Evans (1985) presents a model with sectoral supply bottlenecks.

${ }^{20}$ While consumption taxes will not directly affect labor supply or investment, they may do so indirectly.

${ }^{21}$ For a review of recent empirical evidence related to labor supply, see Blundell and MaCurdy (1999).
} 
possibly contributing to non-Keynesian effects. Such an agreement is more likely with highly centralized unions. Lane and Perotti (1996) also argue that reductions in government employment - which reduce labor demand, weaken unions, lower wages, and thus increase profitability — can be a source of non-Keynesian effects.

New classical models. The distinctive feature of full-fledged new classical models is that prices clear markets, so that fluctuations in output are the result of supply-side shocks and not of changes in aggregate demand. One implication of new classical models, first highlighted by Lucas (1975) and Sargent and Wallace (1975), is that fully anticipated policies affecting aggregate demand (but not aggregate supply) have no effect on growth either in the short term or the longer term. Only unanticipated policies - which reflect either surprises by the government or imperfect information-have an effect, which emerges entirely through the supply side. This does not mean that these models are silent on fiscal policy. However, they focus on the design of optimal fiscal policy, as distinct from the impact of fiscal policy on economic activity (see Lucas and Stokey, 1983; and Chari and Kehoe, 1998).

\section{Institutional Aspects of Fiscal Policy}

The impact of fiscal policy on economic activity can also depend on institutional factors.

Inside and outside lags. Long lags reduce short-term fiscal multipliers. Inside lags reflect the time it takes to recognize that fiscal policy should be changed and then to put appropriate fiscal measures in place. Inside lags are a function of the political process and the effectiveness of fiscal management. Outside lags reflect the time it takes for fiscal measures to feed through to aggregate demand (Blinder and Solow, 1974). All fiscal measures could be subject to long inside lags because their design, approval, and implementation may be protracted. The greater the reliance on discretionary measures, the longer inside lags are likely to be. Generally speaking, automatic stabilizers — usually in the form of progressive income taxes and unemployment compensation-which provide countercyclical impulses to the economy without the need for discretionary measures have shorter inside lags. ${ }^{22,} 23$ Outside lags are more variable, but they will tend to be shorter for transfers and income tax cuts targeted at individuals who are liquidity constrained.

Political economy considerations. Alesina and Perotti (1995) suggest that large and persistent deficits may point to the existence of a deficit bias explained by several political economy factors.

\footnotetext{
${ }^{22}$ Apart from this, there is no reason to believe that fiscal policy changes reflecting automatic stabilizers and discretionary measures will have different effects on output.

${ }^{23}$ Some particular types of fiscal measures, such as changes to the tax structure that affect influential interest groups, increases in public investment that are subject to tendering, and additions to spending that is devolved to lower levels of government, may be more susceptible to inside lags.
} 
- Voters and policymakers may be subject to fiscal illusion (i.e., not be fully aware of the government's intertemporal budget constraint), and therefore favor deficits over surpluses. $^{24}$

- Current voters (and policymakers) may want to shift the burden of fiscal adjustment onto future generations.

- Debt accumulation may be used as a strategic instrument to limit the fiscal room for maneuver of future governments.

- $\quad$ Fiscal consolidations may be delayed by political conflicts regarding the sharing of adjustment costs between various groups, resulting in persistent deficits.

- And finally, existing budget institutions may function in a way that leads to persistently high spending.

Where a deficit bias exists, the positive impact of a fiscal expansion must be weighed against the negative impact of persistently higher deficits that result if the expansion is not fully reversed. If households and firms are completely myopic or liquidity constrained, this may not affect fiscal multipliers. But if households and firms (or financial markets) are at least partially forward-looking, a fiscal expansion that is announced to be temporary may still lead to an increase in the risk premium, or higher private saving, which will reduce fiscal multipliers.

Level of development. Most of the literature on the effectiveness of fiscal policy has been written in an advanced economy context. In principle, almost all of the arguments discussed above should carry over to a developing country setting, although the fact that economic activity is more likely to be influenced by supply shocks in developing countries will present fewer opportunities to use fiscal policy for demand management (Agénor, McDermott, and Prasad, 1999). However, there are institutional features specific to developing countries that will affect the size of fiscal multipliers. On the one hand, the availability and cost of domestic and external financing is often a major constraint on fiscal policy. In highly indebted developing countries that do not have access to international capital markets (or do so only on unfavorable terms), access to financing often determines the size of the fiscal deficit. It then follows that an increase in the fiscal deficit beyond a level that can be financed on acceptable terms will lead to strong crowding out effects. ${ }^{25}$ On the other hand, the relatively

\footnotetext{
${ }^{24}$ However, there is also some evidence that fiscal adjustment can be popular because voters seek to penalize profligate fiscal policies (Alesina, Perotti, and Tavares, 1998).

${ }^{25}$ This argument was made in the case of Asian crisis countries. The main argument for fiscal tightening in the early stage of the crisis was the presence of financing constraints, and it was argued that fiscal policy begins to have a significant stimulative effect only as external financing constraints are relaxed, or additional financing becomes available (Lane and others, 1999).
} 
high marginal propensity to consume in many developing countries would tend to increase the size of the multiplier. Finally, fiscal policy is likely to be harder to implement in developing countries, for several reasons: poor tax administration and expenditure management; governance problems; volatile revenue bases, for example due to heavy reliance on trade taxes; long lags affecting fiscal policy; ${ }^{26}$ and, reflecting some of these and other factors (e.g., the need to subsidize loss-making public enterprises), a greater deficit bias. $^{27}$

\section{The Empirical Literature}

Having identified factors that in principle determine the size and sign of fiscal multipliers, this section reviews the associated empirical literature.

\section{A. Advanced Economies}

The empirical literature on advanced economies has three substantive components. First, there are estimates of fiscal multipliers derived from macroeconomic model simulations and reduced form equations. Second, there are studies that draw lessons by looking across episodes of fiscal contraction, with a special emphasis on identifying expansionary fiscal contractions. While the first two components focus on the size and sign of fiscal multipliers, the third component looks at some of the determinants of fiscal multipliers. In particular, it is concerned with the relationships between fiscal policy, interest rates, investment, and exchange rates, and with tests of Ricardian equivalence.

\section{Estimates of fiscal multipliers from macroeconomic model simulations}

There are two types of macro models used to derive multiplier estimates: large macroeconomic models estimated empirically, such as the IMF MULTIMOD model, and smaller dynamic general equilibrium models which are calibrated and then solved numerically. The appeal of using either type of model to derive fiscal multipliers is that they are able to account for many of the influences identified in Section II, and the interactions between them. However, there can be no single or definitive fiscal multiplier derived from model simulations, because the results will depend on the precise specification of the fiscal policy shock, the monetary policy response function, the extent to which expectations are forward looking, the value of key parameters such as the intertemporal elasticity of labor supply, and so on. Thus simulations typically produce a range of multiplier estimates, which

\footnotetext{
${ }^{26}$ Since automatic stabilizers tend to be weaker in developing countries, inside lags in particular are likely to be longer (Tanzi, 1986).

${ }^{27}$ There may therefore be a particularly strong argument in favor of fiscal rules or institutional arrangements (such as stabilization funds) to reduce the deficit bias in developing countries.
} 
makes it difficult to draw clear conclusions from the evidence provided by different models, across a number of countries, and over time.

\section{Simulations of empirically estimated macroeconomic models}

Tables 1 and 2 summarize the results of a number of studies using macroeconomic models. The main conclusions that emerge are the following.

- In all the studies reviewed, short-term multipliers derived from standard simulations of fiscal policy are positive.

- The range of estimated short-term multipliers is wide, ranging from 0.1 to 3.1 , but most expenditure multipliers are in the range 0.6 to 1.4 , and most tax multipliers in the range $0.3-0.8$. Moreover, there is some evidence that the divergence of multiplier estimates is diminishing over time. For example, compared to the first study to compare standard simulations across a number of macroeconomic models by Bryant and others (1988) the follow-up studies by Bryant, Hooper, and Mann (1993) and McKibbin (1996) found a narrower range of estimates. Saito (1997) reports fiscal multipliers derived from Japan's Economic Planning Agency macroeconomic model have decreased over time. $^{28}$

- Comparing spending multipliers across the G-7 countries, there is some indication that they are larger for Japan than in the United States and Europe. Dalsgaard, André, and Richardson (2001) attribute this to the high short-term sensitivity of investment to output changes in Japan. Among the large European economies, there is a fairly wide range of short term expenditure multipliers, ranging between 0.6 and 1.5 for Germany, for example.

- $\quad$ Most macro models confirm that short-term multipliers are smaller for tax changes than for spending changes. IMF (1996a) finds a short-term tax multiplier for the United States of 0.7 , compared to 1.1 for spending. Tax multipliers are significantly smaller than spending multipliers for the United States, Japan, and Germany in the OECD INTERLINK model (Dalsgaard, André, and Richardson, 2001). Bartolini, Razin, and Symansky (1995) use a version of MULTIMOD to explicitly examine the output effects of different types of fiscal consolidation measures used by G-7 countries in the early 1990s. They conclude that increases in indirect taxes and expenditure cuts have relatively large output costs in the short term (but are less distortionary and can

\footnotetext{
${ }^{28}$ Smaller multipliers probably mainly reflect changes in the structure of the models. Most macroeconomic models used for policy analysis in the 1970s and 1980s were basically Keynesian in structure, with backward-looking expectations. More recent macroeconomic models typically incorporate intertemporal budget constraints and forward-looking expectations, at least for some variables such as exchange rates.
} 
Table 1. Estimates of Multipliers from Macromodel Simulations

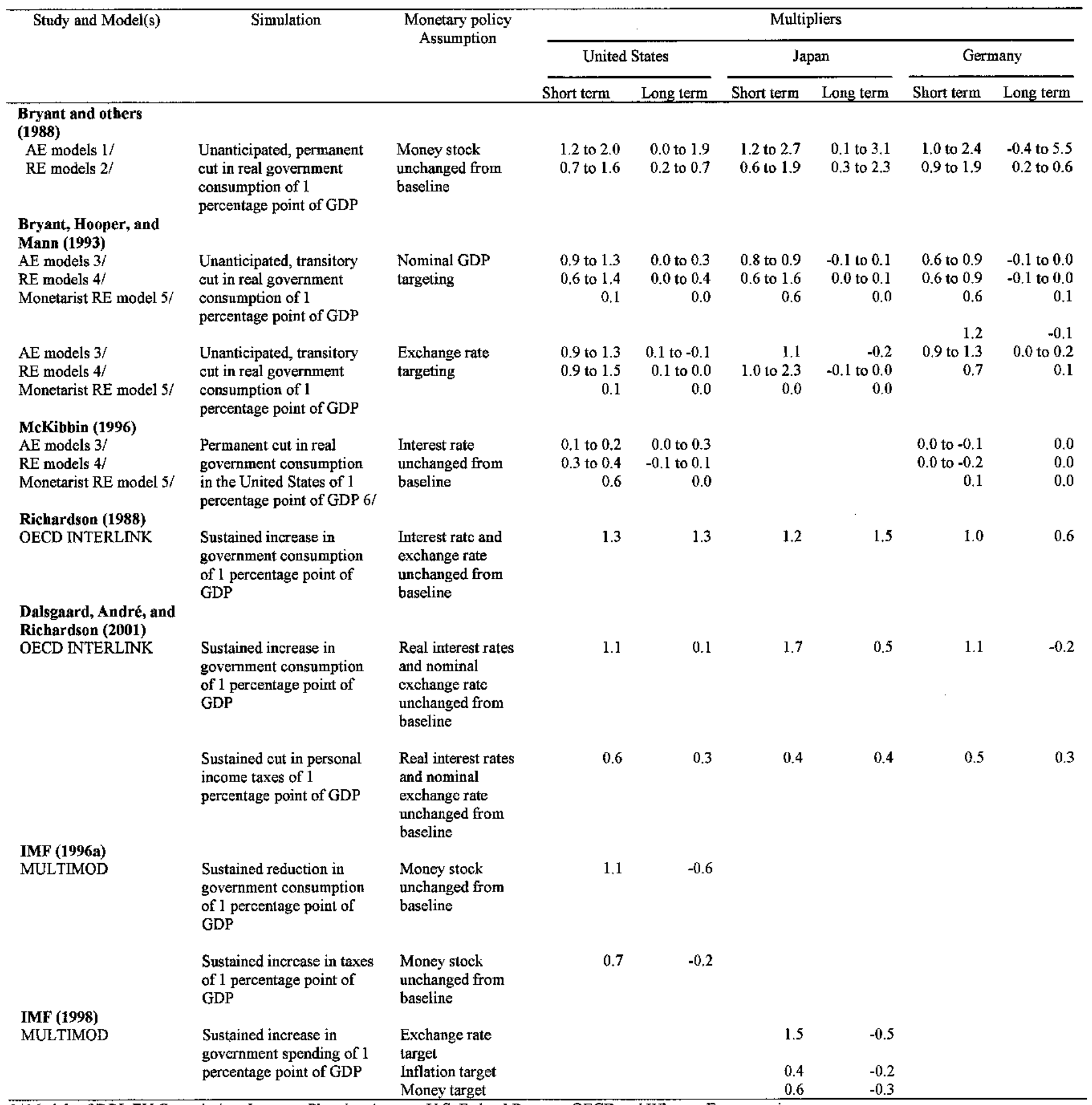

1/ Models of DRI, EU Commission, Japanese Planning Agency, U.S. Federal Reserve, OECD and Wharton Econometrics.

2/ Models include the MeKibbin-Sachs Global model, IMF's MINIMOD, and the multicountry models of John Taylor and Liverpool University.

3/ Models of NIESR, Canadian Department of Finance, OECD, and U.S. Federal Reserve.

4/ Models include the McKibbin-Sachs Global model, IMF's MULTIMOD, and John Taylor's multicountry model.

5/ Patrick Minford's Liverpool model.

6/ For McKibbin (1996) multipliers for Germany are transmission multipliers (i.e., effect of U.S. fiscal action). 
Table 2. Government Expenditure Multipliers in Large European Countries

( 1 percent of GDP reduction in government consumption for one year)

\begin{tabular}{|c|c|c|c|c|c|c|c|c|c|}
\hline \multirow[b]{2}{*}{ Model } & \multirow[b]{2}{*}{$\begin{array}{l}\text { Monetary Policy } \\
\text { Assumption }\end{array}$} & \multicolumn{4}{|c|}{ Short-term Multiplier } & \multicolumn{4}{|c|}{ Long-term Multiplier } \\
\hline & & Germany & France & Italy & $\begin{array}{l}\text { United } \\
\text { Kingdom }\end{array}$ & Germany & France & Italy & $\begin{array}{l}\text { United } \\
\text { Kingdom }\end{array}$ \\
\hline \multirow[t]{2}{*}{$\begin{array}{l}\text { European Commission QUEST } \\
\text { model } 1 /\end{array}$} & $\begin{array}{l}\text { 1. No interest rate } \\
\text { response }\end{array}$ & 0.9 & 0.9 & 0.9 & 1.0 & 0.0 & 0.0 & 0.0 & 0.0 \\
\hline & 2. Price level targeting & 0.6 & 0.8 & 0.7 & 0.5 & 0.0 & 0.0 & 0.0 & 0.0 \\
\hline $\begin{array}{l}\text { IMF } \\
\text { MULTIMOD 2/ }\end{array}$ & $\begin{array}{l}\text { Nominal interest rates } \\
\text { fixed at baseline for } \\
1 \text { year, then inflation } \\
\text { targeting }\end{array}$ & 1.3 & 1.3 & 1.3 & $\mathrm{n} / \mathrm{a}$ & -0.2 & -0.2 & -0.2 & $\mathrm{n} / \mathrm{a}$ \\
\hline $\begin{array}{l}\text { United Kingdom National Institute } \\
\text { of Economic and Social Research } \\
\text { NIGEM model 3/ }\end{array}$ & $\begin{array}{l}\text { Nominal interest rates } \\
\text { fixed at baseline for } \\
1 \text { year, then inflation } \\
\text { targeting }\end{array}$ & 1.0 & 0.8 & 0.7 & 0.6 & 0.0 & 0.0 & 0.0 & -0.1 \\
\hline OECD INTERLINK model 4/ & $\begin{array}{l}\text { Fixed nominal exchange } \\
\text { rates; real interest rates } \\
\text { held at baseline level }\end{array}$ & 1.5 & 0.8 & 1.2 & $\mathrm{n} / \mathrm{a}$ & -0.3 & 0.2 & -0.1 & $\mathbf{n} / \mathbf{a}$ \\
\hline
\end{tabular}

1/ Roeger and in't Veld (2002).

2/ Hunt and Laxton (2002).

3 / Barrell and others (2002).

4/ Dalsgaard, André, and Richardson (2001). 
result in output gains over the long term). By contrast, consolidation relying on higher labor and capital taxes results in smaller output costs (but larger long-term output losses due to higher unemployment and a lower capital stock).

- Most simulations of fiscal shocks under alternative monetary regimes find that the latter has relatively little effect on the size of short-term fiscal multipliers. One exception is Laxton and others (1998), which finds that the fiscal multiplier in Japan is 0.4 and 0.6 under inflation and money targeting respectively, while it is 1.5 with a fixed exchange rate assumption.

- There is very little evidence of negative short-term multipliers from macro-mode] simulations, though few studies explicitly address the effects of credibility. Three studies that do so, Bayoumi and Laxton (1994), IMF (1996b), and IMF (1997), use simulations of MULTIMOD to analyze the effects of debt reduction (through phased cuts in government spending) in Canada, Germany, and Japan, respectively, under different credibility scenarios. These studies conclude that fiscal multipliers are generally positive but small, even when the credibility of fiscal consolidation is low. However, negative multipliers can emerge if fiscal consolidation is highly credible.

- McKibbin (1996) examines "transmission" multipliers (in this case, the effects on Germany of a fiscal action in the United States) and finds them to be positive but small in the short run, and zero after five years.

- Finally, long-term multipliers are generally smaller than short-term multipliers, reflecting crowding out effects; indeed, several models have negative long-term multipliers.

\section{Simulations of calibrated general equilibrium models}

Since the early 1980s, a number of studies have used dynamic general equilibrium models to analyze the steady-state (or long-run) impact effects of fiscal policy on a range of macroeconomic aggregates, including output. Most of the earlier studies used variants of the neoclassical growth model with no market imperfections, ${ }^{29}$ more recent studies have introduced imperfections such as oligopolistic competition (Rotemberg and Woodford, 1993), increasing returns to scale (Devereux, Head, and Lapham, 1996), distortionary taxes (Ludvigson, 1996), or two sectors with costly reallocation of capital across sectors (Ramey and Shapiro, 1998). Almost all models are calibrated on U.S. data; one exception is Ardagna (2001), which uses average data for ten EU countries over the period 1965-95. These and other studies yield the following main conclusions:

\footnotetext{
${ }^{29}$ For example, Hall (1980); Barro (1981 and 1989); Aiyagari, Christiano, and Eichenbaum (1992); and Baxter and King (1993).
} 
Spending multipliers. Almost all studies find that output responds positively to an (unanticipated) increase in government spending. The standard mechanism is as follows: higher government spending implies a reduction in wealth; this reduces consumption, but (assuming leisure to be a normal good) leads to an increase in hours worked and a fall in the real wage; this raises the marginal product of capital. In the long run this means a higher capital stock; in the short run, there is an increase in investment and output, analogous to the Keynesian investment accelerator. The size of the multiplier depends on key parameters such as the intertemporal elasticity of labor supply and the persistence of the shock to government spending, but in most studies is in the range of 0.3 to 1.2. Baxter and King (1993) derive multipliers that are larger over the long run than the short run; but Ramey and Shapiro (1998) have the output response peaking after two periods and falling subsequently, as the negative effect on private consumption builds up.

Temporary versus permanent changes in spending. In contrast to earlier studies, such as Barro 1981, several general equilibrium models (e.g., Aiyagari and others, 1992; Baxter and King, 1993; and Devereux, Head, and Lapham, 1996) find that permanent changes in government consumption have larger output effects than temporary changes. The main reason is that permanent changes in spending will increase the steady-state capital stock and cause a large increase in investment even in the short run, while temporary changes result in more crowding output and a smaller output response.

The role of financing. Baxter and King (1993) examine how the impact of permanent and temporary spending increases differ if they are financed by an increase in (distortionary) taxes. For a permanent spending change, the tax rate must rise, which reduces incentives to work and invest, reducing the tax base; taxes must therefore increase by more than spending as a share of output. For plausible parameter values, but fixed labor input, they calculate the multiplier to be -1.1; with elastic labor supply the multiplier can reach -2.5 . A temporary spending increase financed by higher taxes also has a negative impact on output, even in the short run, as the higher taxes reduce labor supply and investment. Ludvigson (1996) finds similar results.

Type of government spending. Ardagna (2001) compares the output effects of a permanent, unanticipated debt-financed increase in government spending on final goods and employment. The former results in a small but positive impact multiplier, but the latter has a larger and negative effect on output, even in the short run and even when the increase in spending is financed by lump-sum taxes. Higher public employment reduces labor input in the private sector, which offsets the positive effects of lower wealth. ${ }^{30}$ However, the sign of the multiplier can be reversed if public employment is assumed to have a positive effect on the productivity of capital and labor in the private sector. In a similar vein, Baxter and King (1993) find that increases in public investment can have positive output effects in the short run if that investment increases the marginal productivity of private capital. With inelastic

\footnotetext{
${ }^{30}$ Finn (1998) finds qualitatively similar results.
} 
labor supply the long run multiplier is 1.7 ; when productive public investment is combined with elastic labor supply, the long run multiplier increases dramatically, and can exceed 5.

Tax multipliers. Dotsey (1994) demonstrates that the effect on output of a deficit-financed tax cut depends on the type of taxation assumed. A deficit-financed cut in distortionary capital taxes can expand output, provided the increase in debt is paid for by lump-sum taxes. But deficit-financed tax cuts paid for by higher income taxes in the future can reduce output in the short run. Ludvigson (1996) shows how these findings also depend on the elasticity of labor supply and the degree of persistence in the positive debt shock. With more elastic labor input, a tax cut subsequently financed by higher distortionary taxes can still increase output; but this effect is offset as the assumed persistence of the debt shock increases. Finally, Ardagna (2001) finds that output declines on impact following increases in income and capital taxes, with the former having much larger output effects.

\section{Reduced form equation estimates of fiscal multipliers}

\section{United States}

There are a number of studies using time-series data for the United States which look at the impact of fiscal policy on output. Earlier studies estimated a reduced form equation for output including one or more explanatory variables capturing discretionary fiscal policy changes. Barro (1981) finds that temporary changes in defense spending (primarily, those associated with wartime) have strong positive effects on output, implying a multiplier in the range $0.6-0.8$; permanent shifts in defense spending have a weaker but still positive effect on output, with a multiplier in the range $0.2-0.6$; the coefficient for changes in permanent nondefense spending is not significant. Eisner (1989), using the "high employment surplus" estimated by the Congressional Budget Office as the measure of fiscal policy, finds much larger multiplier effects-around 2.5 for the period 1966-83, and 1.8 for 1956-66-but the estimates are not robust. Romer and Romer (1994) and Perry and Schultze (1993) include variables to control for monetary policy and lags, and derive significantly smaller fiscal multipliers, closer to those yielded by simulation models.

One response to the endogeneity problem inherent in estimating the effect of fiscal policy on activity is to identify exogeneous fiscal shocks more precisely. Ramey and Shapiro (1997) identify three episodes of sharply increased military spending (1950Q3, 1965Q1, and $1980 \mathrm{Q} 1$ ) and use these as dummy variables in univariate auto-regressive equations for GDP. They find a positive and significant effect of the defense spending shock on GDP on impact, and after 4-6 quarters, but this falls to zero within three years following the shock. Edelberg, Eichenbaum, and Fisher (1999) use the same dummies in a VAR framework, and find a similar response of GDP: increasing over the first year to become statistically significant 4-8 quarters after the shock, before declining. The key findings of a number of other studies which have used VAR techniques to examine the output effects of fiscal shocks are shown in 
Table $3{ }^{31}$ For government spending shocks, impact effects are all positive, but range between 0.1 and 0.9 . In most cases the positive effects on GDP increase over the following quarters, but the timing of the peak impact varies widely. In all studies the positive effect of higher spending on output wears off over time; in one case the effect on GDP is negative 5 years after the shock. Impact effects are smaller for tax cuts, though in some cases the long-term effects are larger than for spending shocks.

Weber (1999) uses a different strategy to estimate long run and impact multipliers from post-War U.S. data, based on a cointegrating regression and error correction model respectively. He finds the long run multiplier exceeds unity, and ranges between 1.1 and 1.4; the impact multiplier is also positive, but much smaller, in the range 0.10 to 0.13 . These estimates are very close to those found by Baxter and King (1993).

\section{Japan}

The prolonged slowdown in Japanese growth in the 1990s, and the authorities' use of active fiscal policy in an attempt to stimulate activity, has prompted a number of recent studies estimating fiscal multipliers using time series data. Most of these studies find multiplier estimates that are significantly smaller than those derived from macroeconomic model simulations.

- $\quad$ Matsuoka (1996), using a VAR model, estimates the short-term spending multiplier to be 0.4 at most, and more likely around -0.2 . He explains the negative multiplier as a response by Japanese consumers to increasing concern about an aging population, which leads them to increase saving by more than enough to offset higher government spending.

- $\quad$ Three recent IMF studies estimate short-run spending multipliers of around $1 / 2$. IMF (1998), using OLS techniques, finds a spending multiplier 0.6; Bayoumi (2000), estimating a VAR model, finds a larger impact multiplier for government spending of around 0.7 , though the stimulus wears off quickly ${ }^{32}$; and IMF (2002b), using a structural VAR model, finds the impact multiplier of government spending to be around 0.4 .

\footnotetext{
${ }^{31}$ The studies cited in Table 3 use different approaches to identify fiscal shocks. Blanchard and Perotti (2002) and Perotti (2002) rely on institutional information about the tax and transfer system and the timing of tax collections to separate out the automatic response of taxes and spending to activity, and hence to isolate fiscal shocks; Mountford and Uhlig (2002) rely on sign restrictions on impulse responses; and Fatás and Mihov (2001) use a Choleski ordering approach, assuming that government spending does not react to economic conditions within a quarter.

${ }^{32}$ Bayoumi (2000) argues that these muted multiplier effects are consistent with uncertainty about the timing and "real water" content of, and low social rates of return on, much public investment expenditure of the 1990 s.
} 
Table 3. Effects of Fiscal Policy on Output (VAR Estimates)

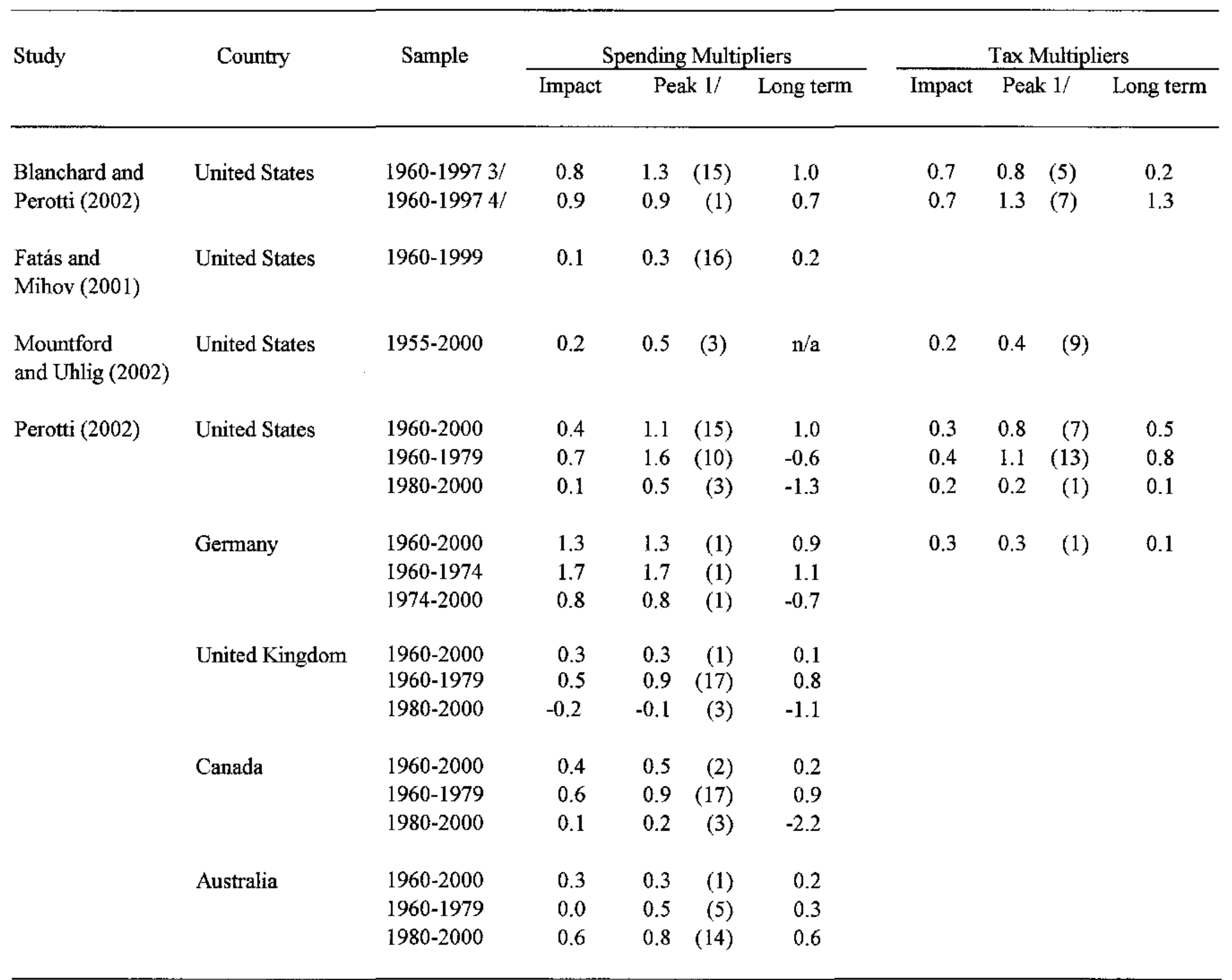

1/ Figures in parentheses are quarters after impulse when peak response occurs.

2/ Assuming deterministic trend for output.

3/ Assuming stochastic trend for output. 
- These studies generally find the tax multiplier to be smaller: insignificantly different from zero in IMF (1998); around 0.2 in Bayoumi (2000); but somewhat higher, at around 0.4, in IMF (2002b). Bayoumi says the small tax multipliers are consistent with the view that Japanese consumers have become increasingly Ricardian with the increase in public debt, and with the temporary nature of many of the tax cuts of the $1990 \mathrm{~s}$.

- However, a recent study by Kuttner and Posen (2002), using the structural VAR approach developed in Blanchard and Perotti (2002), finds much larger spending and tax multipliers. Their estimated impulse response functions are similar in magnitude to those found for the United States by Blanchard and Perotti, but Kuttner and Posen calculate fiscal multipliers by cumulating the impact of tax and spending shocks over several years; this method gives a spending multiplier of 2.0 and a tax multiplier of 2.5 after four years.

- $\quad$ Finally, IMF (2002b) finds that long-run spending multipliers are much smaller for the 1981-2000 period compared to 1961-80, due to lower long-run multipliers for both investment and consumption spending, and a shift in the composition of spending towards transfers.

\section{Other advanced economies}

Several recent papers have applied the structural VAR approach developed in Blanchard and Perotti (2002) to other advanced economies:

- Bruneau and de Bandt's (1999) report estimates for France and Germany over the period 1972-95 imply that fiscal shocks have had almost no effect on output in France in the short term, but a more significant impact in Germany, with the multiplier peaking at around 0.8 between three and six quarters following the shock. The authors argue that they are measuring the degree of fiscal activism, with French fiscal policy generally having been more passive than German fiscal policy since the early 1970 s.

- van Aarle, Garretsen, and Gobbin (2001) estimate fiscal multipliers for the euro area as a whole and for 15 EU countries individually. For the former, the short-run response to a spending shock is positive (and similar in size to estimates for the United States and Japan) but turns negative after just 2 quarters, and remains non-Keynesian thereafter. For a tax shock, the impact multiplier is of the standard positive sign, but becomes negative (albeit small) after 8 or 9 quarters. Repeating the exercise for individual EU countries, the authors find considerable variation in the size and sign of multipliers; this could explain the limited impact of fiscal policy shocks at the level of the euro area.

- $\quad$ Perotti (2002) includes estimates for Germany, the United Kingdom, Canada, and Australia, in addition to the United States. He also estimates the effects of tax and spending shocks on GDP over two subperiods, 1960-79 and 1980-2000. For spending shocks, the effects are similar in size to the United States, except in the case of Germany where the positive effects are considerably stronger. Perotti also finds a consistent pattern across countries of smaller multiplier effects in the 1980s and 1990s than in the previous two decades. 
- $\quad$ Finally, for the United Kingdom, IMF (2002a) finds that multipliers for spending and tax shocks are statistically insignificant; one exception is the multiplier on transfers, which is significant (and positive) but small. ${ }^{33}$

\section{Episodes of fiscal contraction}

Beginning with Giavazzi and Pagano (1990), there is now a fairly large number of empirical studies which conclude that some fiscal contractions in OECD countries have had an expansionary short-term impact on the economy. ${ }^{34}$ While these studies differ in terms of their samples and methodology, the approach adopted is broadly the same. Each study subjects a cross section of fiscal consolidation episodes over a 10-35 year period to analysis with a view to identifying those with expansionary effects on activity, isolating the channels through which they occur, and describing some of their characteristics. Fiscal consolidations are usually defined relative to a specific percentage point of GDP change in the primary structural deficit over a 1-3 year period. In addition, some studies distinguish successful from unsuccessful fiscal consolidations by reference to the size of the fiscal adjustment, its duration, or its impact on the debt-to-GDP ratio. Some studies also supplement cross-section analysis with relevant case studies. ${ }^{35}$

Table 4 provides information on ten cross-section studies. The main conclusions of these studies are as follows.

- All studies identify expansionary fiscal contractions. Giavazzi and Pagano's key finding, namely that Denmark (1983-86) and Ireland (1987-89) are the clearest instances of expansionary fiscal contractions, is generally confirmed.

- Growth rates tend to respond more favorably to episodes of successful fiscal consolidation than to episodes of unsuccessful consolidation. ${ }^{36}$ The same is true of unemployment rates. ${ }^{37}$ However, the quantitative impact of fiscal consolidation - that is the size of the associated (negative) multipliers - varies markedly across successful and unsuccessful consolidations.

\footnotetext{
${ }^{33}$ One earlier study of the United Kingdom, not using VAR techniques, is Ahmed (1986). Using data for the period 1908-80, the multiplier is estimated as $0.2-0.6$ for temporary increases in (military) spending; the results for permanent changes in spending are less well determined and are sensitive to other aspects of the specification.

${ }^{34}$ The literature also refers to fiscal "consolidations" and "adjustments" as well as contractions.

${ }^{35}$ Alesina and Ardagna (1998) go furthest in this regard, examining in detail ten fiscal contractions.

${ }^{36}$ Successful fiscal consolidations are larger, of longer duration, or have a significant impact on the debt ratio.

${ }^{37}$ Growth rates and unemployment rates are defined relative to the weighted average of G-7 or OECD countries.
} 


\section{Table 4. Cross-Section Studies of Expansionary Fiscal Contractions}

\begin{tabular}{|c|c|c|c|c|}
\hline & Sample & Definition of Contraction & $\begin{array}{l}\text { Number of } \\
\text { Episodes }\end{array}$ & Type of Analysis \\
\hline $\begin{array}{l}\text { McDermott and } \\
\text { Westcott (1996) }\end{array}$ & $\begin{array}{l}20 \text { OECD countries, } \\
1970-95\end{array}$ & $\begin{array}{l}\text { Primary structural balance improves } \\
\text { by at least } 1 \frac{1 / 2}{2} \text { percentage points of } \\
\text { GDP over two years. }\end{array}$ & 74 & $\begin{array}{l}\text { Correlations of averages } \\
\text { across groups of episodes. }\end{array}$ \\
\hline $\begin{array}{l}\text { Giavazzi and } \\
\text { Pagano (1996) }\end{array}$ & $\begin{array}{l}19 \text { OECD countries, } \\
1970-92\end{array}$ & $\begin{array}{l}\text { Any period when the primary } \\
\text { structural balance moved in a } \\
\text { consistent direction; a cumulative } \\
5 \text { percentage point of GDP change } \\
\text { marks a "large" consolidation. }\end{array}$ & 223 & $\begin{array}{l}\text { Panel regressions of } \\
\text { consumption functions (error } \\
\text { correction specification). }\end{array}$ \\
\hline $\begin{array}{l}\text { OECD } \\
(1996)\end{array}$ & $\begin{array}{l}\text { All OECD } \\
\text { countries, } 1975-95\end{array}$ & $\begin{array}{l}\text { Primary structural balance improves } \\
\text { by } 3 \text { percentage points of GDP in } \\
\text { consecutive years. }\end{array}$ & 15 & $\begin{array}{l}\text { Correlations of averages } \\
\text { across groups of episodes. }\end{array}$ \\
\hline $\begin{array}{l}\text { Cour and others } \\
\text { (1996) }\end{array}$ & $\begin{array}{l}17 \text { OECD countries, } \\
1970-94\end{array}$ & $\begin{array}{l}\text { Continuous improvement in primary } \\
\text { structural balance, including an } \\
\text { "intense" subperiod. }\end{array}$ & 19 & $\begin{array}{l}\text { Correlations of averages } \\
\text { across groups of episodes, } \\
\text { consumption functions } \\
\text { estimated across countries. }\end{array}$ \\
\hline $\begin{array}{l}\text { Alesina and } \\
\text { Perotti (1997) }\end{array}$ & $\begin{array}{l}20 \text { OECD countries, } \\
1960-94\end{array}$ & $\begin{array}{l}\text { Primary structural balance improves } \\
\text { by at least } 1 \frac{1}{2} \text { percentage points of } \\
\text { GDP in one year or } 11 / 4 \text { percentage } \\
\text { points in two consecutive years. }\end{array}$ & $\begin{array}{l}62 \text { years of tight } \\
\text { fiscal policy }\end{array}$ & $\begin{array}{l}\text { Correlations of averages } \\
\text { across groups of episodes. }\end{array}$ \\
\hline $\begin{array}{l}\text { Alesina and } \\
\text { Ardagna (1998) }\end{array}$ & $\begin{array}{l}\text { All OECD } \\
\text { countries, } 1960-94\end{array}$ & $\begin{array}{l}\text { Primary structural balance improves } \\
\text { by } 2 \text { percentage points of GDP in } \\
\text { one year or by } 1 \frac{1}{2} \text { percentage points } \\
\text { of GDP in two consecutive years. }\end{array}$ & $\begin{array}{l}51 \text {, of which } \\
23 \text { expansionary }\end{array}$ & $\begin{array}{l}\text { Correlations of averages } \\
\text { across groups of episodes. }\end{array}$ \\
\hline $\begin{array}{l}\text { Alesina, Perotti, } \\
\text { and Tavares } \\
(1998)\end{array}$ & $\begin{array}{l}19 \text { OECD countries, } \\
1960-95\end{array}$ & $\begin{array}{l}\text { Primary structural balance improves } \\
\text { by } 1 \frac{1 / 2}{2} \text { percentage points of GDP in } \\
\text { one year. }\end{array}$ & $\begin{array}{l}69, \text { of which } \\
19 \text { successful }\end{array}$ & $\begin{array}{l}\text { Correlations of averages } \\
\text { across groups of episodes. }\end{array}$ \\
\hline Perotti (1999) & $\begin{array}{l}19 \text { OECD countries, } \\
1965-94\end{array}$ & Not given. & Not given & $\begin{array}{l}\text { Panel regressions of } \\
\text { consumption functions (Euler } \\
\text { equation specification). }\end{array}$ \\
\hline $\begin{array}{l}\text { Giavazzi, } \\
\text { Jappelii, and } \\
\text { Pagano }(2000)\end{array}$ & $\begin{array}{l}18 \text { OECD countries, } \\
1970-96\end{array}$ & & $\begin{array}{l}38 \text { expansions, } \\
65 \text { contractions }\end{array}$ & $\begin{array}{l}\text { Panel regressions of national } \\
\text { saving rates. }\end{array}$ \\
\hline $\begin{array}{l}\text { Alesina, and } \\
\text { others (2002) }\end{array}$ & $\begin{array}{l}18 \text { OECD countries, } \\
1960-96\end{array}$ & $\begin{array}{l}\text { Primary structural balance improves } \\
\text { by at least } 2 \text { percentage points of } \\
\text { GDP in one year or } 11 / 4 \text { percentage } \\
\text { points of GDP in two consecutive } \\
\text { years. }\end{array}$ & Not given & $\begin{array}{l}\text { Correlations of averages } \\
\text { across groups of episodes, } \\
\text { investment equations from } \\
\text { pooled regressions. }\end{array}$ \\
\hline
\end{tabular}




\section{Table 4. Cross-Section Studies of Expansionary Fiscal Contractions (concluded)}

\begin{tabular}{|c|c|c|c|}
\hline & Main Evidence of Expansionary Contractions & Channels & $\begin{array}{c}\text { Characteristics of Expansionary } \\
\text { Contraction }\end{array}$ \\
\hline $\begin{array}{l}\text { McDermott } \\
\text { and Westcott } \\
(1996)\end{array}$ & $\begin{array}{l}\text { For successful consolidations, GDP growth } \\
\text { rate relative to OECD average: }-0.2 \text { percent } \\
\text { (before), } 0.1 \text { percent (during) and } 0.7 \text { percent } \\
\text { (after). }\end{array}$ & $\begin{array}{l}\text { For expansionary contractions, } \\
\text { mostly through investment; for } \\
\text { debt-increasing expansions, crowding } \\
\text { out of investment; for stable debt } \\
\text { expansions, growth via consumption. }\end{array}$ & $\begin{array}{l}\text { Size is important, as composition; } \\
\text { expenditure cuts (especially transfers } \\
\text { and government wages) more likely to } \\
\text { be successful; timing with respect to } \\
\text { world business cycle also important. }\end{array}$ \\
\hline $\begin{array}{l}\text { Giavazzi and } \\
\text { Pagano } \\
\text { (1996) }\end{array}$ & $\begin{array}{l}\text { For large/persistent consolidations, } \\
\$ 1 \text { increase in taxes (cut in transfers) raises } \\
\text { private consumption by } 15-20 \mathrm{c} \text { in long run. }\end{array}$ & $\begin{array}{l}\text { Private sector consumption (other } \\
\text { channels not tested). }\end{array}$ & $\begin{array}{l}\text { Size and persistence most important; } \\
\text { clearer effects for government } \\
\text { spending but also for taxes and } \\
\text { iransfers. }\end{array}$ \\
\hline $\begin{array}{l}\text { OECD } \\
(1996)\end{array}$ & $\begin{array}{l}\text { Four of } 15 \text { consolidations had growth above } \\
\text { potential and six were within I percentage } \\
\text { point of potential. }\end{array}$ & Not addressed. & $\begin{array}{l}\text { Supportive monetary policy helps } \\
\text { avoid adverse activity consequences. }\end{array}$ \\
\hline $\begin{array}{l}\text { Cour and } \\
\text { others (1996) }\end{array}$ & $\begin{array}{l}\text { Large retrenchments on average led to } \\
0.1 \text { percent reduction in G- } 7 \text { corrected } \\
\text { growth, but small retrenchments led to } \\
0.4 \text { percent reduction. Non-Keynesian } \\
\text { retrenchments had higher growth rate of } \\
\text { private consumption than predicted by a } \\
\text { standard consumption function. }\end{array}$ & Consumption most important. & $\begin{array}{l}\text { Size most important; other factors not } \\
\text { clear. }\end{array}$ \\
\hline $\begin{array}{l}\text { Alesina and } \\
\text { Perotti (1997) }\end{array}$ & $\begin{array}{l}\text { For successful consolidations, GDP growth } \\
\text { rate relative to OECD average: }-0.2 \text { percent } \\
\text { (before), } 1.1 \text { percent (during), and } \\
0.3 \text { percent (after). }\end{array}$ & $\begin{array}{l}\text { Emphasizes impact on unit labor } \\
\text { costs and competitiveness, and hence } \\
\text { on investment and exports. }\end{array}$ & Composition is crucial. \\
\hline $\begin{array}{l}\text { Alesina and } \\
\text { Ardagna } \\
(1998)\end{array}$ & $\begin{array}{l}\text { For expansionary contractions, GDP growth } \\
\text { rate relative to G- } 7 \text { average: } 0.2 \text { percent } \\
\text { (before), } 1.3 \text { percent (during), and } \\
0.9 \text { percent (after). }\end{array}$ & $\begin{array}{l}\text { Supply side/labor market more } \\
\text { important than demand side; } \\
\text { investment and exports especially } \\
\text { responsive to composition. }\end{array}$ & $\begin{array}{l}\text { Composition more important than size; } \\
\text { incomes policy and exchange rate } \\
\text { depreciation are important } \\
\text { preconditions. }\end{array}$ \\
\hline $\begin{array}{l}\text { Alesina, } \\
\text { Perotti, and } \\
\text { Tavares } \\
\text { (1998) }\end{array}$ & $\begin{array}{l}\text { For successful consolidations, GDP growth } \\
\text { rate relative to OECD average: }-0.3 \text { percent } \\
\text { (before), } 0.1 \text { percent (during), and } \\
0.2 \text { percent (after). }\end{array}$ & $\begin{array}{l}\text { Investment more important than } \\
\text { consumption; labor market also } \\
\text { important. }\end{array}$ & $\begin{array}{l}\text { Composition more important than size; } \\
\text { labor market structure also important. }\end{array}$ \\
\hline Perotti (1999) & $\begin{array}{l}\text { Expenditure shocks have Keynesian effects } \\
\text { with low debt or deficits, but non-Keynesian } \\
\text { effects with high debt or deficits; evidence on } \\
\text { a similar switch with tax shocks is less } \\
\text { strong. }\end{array}$ & $\begin{array}{l}\text { Private sector consumption (other } \\
\text { channels not tested). }\end{array}$ & $\begin{array}{l}\text { Initial fiscal conditions are crucial; } \\
\text { composition also important. }\end{array}$ \\
\hline $\begin{array}{l}\text { Giavazzi, } \\
\text { Jappelli, and } \\
\text { Pagano } \\
(2000)\end{array}$ & $\begin{array}{l}\text { Non-Keynesian responses by private sector } \\
\text { more likely when fiscal impulses are large } \\
\text { and persistent. }\end{array}$ & $\begin{array}{l}\text { Private sector consumption/saving } \\
\text { (other channels not tested). }\end{array}$ & $\begin{array}{l}\text { Size and persistence most important; } \\
\text { initial fiscal conditions not important. } \\
\text { Non-Keynesian effects larger for } \\
\text { changes in taxes than spending, and } \\
\text { for contractions rather than } \\
\text { expansions. }\end{array}$ \\
\hline $\begin{array}{l}\text { Alesina, and } \\
\text { others }(2002)\end{array}$ & $\begin{array}{l}1 \text { percent cut in primary spending leads to } \\
0.2 \text { percent increase in investment on impact } \\
\text { and } 0.8 \text { percent increase after } 5 \text { years, similar } \\
\text { effects for } 1 \text { percent increase in labor taxes; } \\
\text { larger effects for cuts in government wages. }\end{array}$ & $\begin{array}{l}\text { Tax and spending affect labor costs, } \\
\text { and hence profits and investment. }\end{array}$ & Composition is crucial. \\
\hline
\end{tabular}


- The characteristics of expansionary fiscal contractions are unclear. Some studies, such as Cour and others (1996); Giavazzi and Pagano (1996); and Giavazzi, Jappelli, and Pagano (2000) find that large consolidations are most effective. The several studies associated with Alesina and Perotti emphasize instead the composition of adjustment, and in particular the gains from cutting transfers and other forms of unproductive spending. McDermott and Westcott (1996) conclude that both the size and composition of fiscal consolidation are important.

- Initial fiscal conditions and the other economic policies that accompany fiscal consolidation may also play a role. While some studies find no evidence that these things are important, OECD (1996), Alesina and Ardagna (1998), and Perotti (1999) suggest that the initial level of debt, an exchange rate depreciation preceding consolidation, wage restraint, and/or fiscal consolidation in the context of broader structural reform influence whether a fiscal contraction is expansionary.

- Finally, the investment response to fiscal consolidation is important in some studies. Although the theoretical literature emphasizes the role of private consumption, Alesina and Ardagna (1998) and Alesina and others (2002) find that the behavior of investment prior to, during, and after fiscal consolidations is also a significant, and in some cases more important, determinant of growth.

While the cross-section studies do not provide uniformly clear and strong conclusions, the fact that there have been episodes of expansionary fiscal contraction, and that some episodes share certain characteristics, is difficult to dispute. However, caution is needed in drawing more general conclusions about the design of fiscal policy from these episodes. First, there is a possible sample selection bias problem, in that country cases which are handpicked to provide examples of contrasting outcomes, that is expansionary and contractionary fiscal contractions, should be expected to provide stronger conclusions than a large cross section of fiscal consolidation episodes. Thus they ignore planned contractions that are aborted because their adverse impact on growth is severe (Cour and others, 1996). There is also an emphasis on larger, quite rapid contractions, and many slower, more drawn out contractionary episodes are ignored (see the discussion of Alesina and Ardagna, 1988).

Eichengreen (1998) also points to the possibility of simultaneity bias, in that instead of fiscal consolidation increasing growth, the increase in growth may reduce the fiscal deficit. ${ }^{38}$ It is also possible that omitted variables may explain the correlation between changes in the fiscal deficit and economic activity in some studies. In particular, exchange rate depreciations that accompany expansionary fiscal contractions could directly influence growth more than fiscal policy. This is not systematically taken into account (see the comments by Drazen, 1990).

\footnotetext{
${ }^{38}$ Most studies attempt to control for these effects by using cyclically adjusted measures of the deficit, and the results across many studies appear to be robust with respect to different methods of cyclical adjustment. Giavazzi and Pagano (1996) explicitly address the possibility of simultaneity/endogeneity by estimating consumption equations using two-stage least squares, but still find non-Keynesian effects of fiscal contractions.
} 
The development of the financial sector, which could affect the response of consumers to changes in fiscal policy, tends also to be ignored.

In addition, it has been argued that cross-section studies may be affected by measurement problems. In particular, Obstfeld (1998) points to the inadequacy of the conventionally measured fiscal deficit as a basis for assessing fiscal policy changes, since it does not take into account fiscal reforms with small budgetary consequences but potentially large output effects (e.g., pension reforms). Attention has also been drawn to the fact that empirical studies are not based on explicit models that generate expansionary fiscal contractions (see Barry and Devereux, 1994 and Gali, 1998). For example, Giavazzi and Pagano (1996) emphasize the role of wealth/consumption effects and expectations, based on the comments of Blanchard (1990) on their earlier work, but do not specify and estimate a model that describes how this channel works.

Two recent studies examine the possibility of expansionary fiscal contractions using larger panels of data. von Hagen, Hughes-Hallett, and Strauch (2001) estimate an independent system of equations for real GDP growth, fiscal policy (measured by changes in the cyclically adjusted primary deficit) and monetary policy, for 20 OECD countries over the period 1973-88. They find that output growth falls by 0.1 percent in the year following a 1 percent fiscal tightening. When they estimate the same model for EU countries only, and over the period 1990-98, they find the output cost of fiscal consolidation is insignificantly different from zero. This is consistent with non-Keynesian effects of fiscal policy, but does not suggest that fiscal consolidation in the EU during the run-up to monetary union was actually expansionary.

Finally, Hemming, Mahfouz, and Schimmelpfennig (2002) examine a large cross section of episodes of recession in advanced economies to assess the impact of fiscal policy on activity during and after those recession episodes. They conclude that fiscal policy is usually Keynesian during recessions in closed economies, but that multipliers are unlikely to exceed unity; and that multipliers are smaller for open economies (and probably close to zero when the exchange rate is floating). Nonetheless, they argue that fiscal expansions can be an effective response to recession under the right circumstances (i.e., when there is excess capacity, a closed economy or fixed exchange rate, big government, expenditure-based policy actions, and an accompanying monetary expansion).

\section{Determinants of crowding out}

\section{Money demand}

As noted in Section II, the extent of crowding out depends in part on how interest rates respond to a fiscal expansion, and this in turn reflects the interest and income elasticities of money demand. The empirical evidence, surveyed in Goldfeld and Sichel (1990), suggests that for advanced economies the interest elasticity of money demand is negative and small (typically in the range from -0.02 to -0.05 in the short term, and about three times larger in the long term), while the income elasticity is positive and higher (0.1-0.2 in the short term, 
and unity in the long term). These results suggest that if interest rates are sensitive to fiscal policy, and if investment responds to interest rates, then crowding out could be significant.

\section{Interest rates}

The impact of fiscal policy on interest rates appears to be quite small, although there is some variation across studies. Thus Blanchard and Summers (1984) conclude that most of the increase in interest rates in the United States during the early 1970s was due to higher stock market returns. Barro (1992) finds a somewhat larger short-term effect from public debt (a 1 percent of GDP increase in debt increases interest rates by 12 basis points), also for the United States. And while Evans (1987) finds a positive effect from government spending in six advanced economies, he can identify no effect from fiscal deficits.

To allow for the effects of capital mobility, a number of empirical studies have focused on the impact of worldwide fiscal policies on the global interest rate rather than on domestic interest rates. However, the results are also unclear. Barro and Sala-i-Martin (1990) use weighted averages of a set of domestic interest rates to derive the global interest rate, and find no effect of fiscal variables. But using a similar approach, Tanzi and Lutz (1993) find that a 1 percentage point of GDP increase in gross general government debt increases real interest rates by about 20 basis points in the G-3, G-7, and G-13 countries, and the effect of deficits is much larger. Similarly, using principal components of domestic interest rates, Ford and Laxton (1995) find that a 1 percentage point of GDP increase in OECD net public debt increases the global interest rate by about 30 basis points. And using a common trend of a set of domestic interest rates, Brunner and Kaminsky (1994) find that fiscal shocks in the United States have a positive and significant impact on interest rates in the G-3 countries. Helbling and Wescott (1995) distinguish between long- and short-term relationships (using an error correction model), and find that a 1 percentage point increase in the ratio of world gross debt-to-GDP increases the global short-term equilibrium real interest rate by 16-20 basis points, with a smaller impact on the long-term equilibrium interest rate.

Whereas most studies estimate an equation derived from a saving-investment balance, with determinants of saving and investment as independent variables and a real interest rate as the dependent variable, some studies use a model of the interest rate term structure, assuming efficient capital markets. In this case, the dependent variable is the excess return (or risk premium), and measures of unanticipated changes in fiscal (and other) policies are independent variables. Both Plosser (1982) and Evans (1987) find a positive impact from government spending on the excess return, but no significant impact from fiscal deficits or debt. $^{39}$

\footnotetext{
${ }^{39}$ Although these papers do not explicitly refer to risk premia or credibility effects, the excess return can be interpreted as a risk premium, and the estimated relationship as a measure of fiscal shocks on the risk premium.
} 


\section{Investment}

Even if fiscal policy has some direct impact on interest rates, crowding out still depends on the relationship between interest rates and investment. However, investment does not appear to be sensitive to interest rates. Hence, there is little evidence of crowding out through interest rates. A comprehensive survey of the empirical investment literature by Chirinko (1993) concludes that investment is determined more by output and other quantity variables than by the user cost of capital. Thus for the United States, Clark (1979) and Blanchard (1986) conclude that there is little or no empirical evidence that the cost of capital affects investment demand. Fazzari (1994) finds a negative effect only for the subsample of slow-growing firms. And while Zarnowitz (1999) finds a negative and significant effect, the magnitude is very small.

Results from other advanced economies tend to be similar to those for the United States. Ford and Poret (1990) find that the interest-sensitivity of investment is insignificant across major OECD countries, and that output is the key determinant of investment. Rather than look at the interest rate or the cost of capital, Catinat and others (1987) investigate the empirical significance of a relative price effect, defined as the ratio of wages to the user cost of capital, across OECD countries. Although output is again found to be the key determinant of investment, the relative price effect ranges from negligible in France to somewhat important in the Netherlands.

\section{The exchange rate and the current account}

In an open economy, fiscal multipliers will be reduced to the extent that the exchange rate is flexible and capital is mobile. Many studies therefore look at the relationship between fiscal policy, the exchange rate, and the current account, particularly for the United States.

Fiscal policy and the exchange rate. Among the studies that have focused on movements in the U.S. dollar in the 1980s, some, including Feldstein (1986); Throop (1989); Melvin, Schlagenhauf, and Talu (1989); and Beck (1993), find a positive and significant relationship between fiscal expansion and the exchange rate, reflected both in daily movements of the nominal rate in response to news on fiscal policy, and longer-term trends in the real exchange rate. But other studies, including Evans (1986); McMillin, Douglas, and Koray (1990); Koray and Chan (1991); and Kramer (1995), do not find a statistically significant relationship.

The empirical evidence on the role of fiscal policy in explaining the movements of ERM currencies in the early 1990s, summarized in IMF (1995), is also ambiguous. For example, Caramazza (1993) finds strong effects of fiscal variables on realignment expectations in the post-1987 period; but Chen and Giovannini (1993), looking at a longer period, find that fiscal deficits in Italy, France, and Germany have no such effect. However, in a VAR study for Germany, Japan, the United Kingdom, and Sweden, Ibrahim and Kumar (1996) find that (unexpected) fiscal expansions do appreciate the real exchange rate and worsen the current account, though the effects are not statistically significant. So overall, the extent of crowding out through the exchange rate is not likely to be important. 
Fiscal policy and the current account. Reflecting the ambiguity of the exchange rate effects of fiscal policy, studies of the relationship between the fiscal and trade deficits in the United States also fail to provide clear conclusions. While Bernheim (1988), and Miller and Russek (1989) conclude that the fiscal deficit is a prime determinant of the trade deficit, Evans (1989) and Dewald and Ulan (1990) find no such causal link. Other studies are less conclusive. Enders and Lee (1990), for example, find that changes in government spending do generate current account deficits, but the evidence on whether switching between debt and taxes to finance a fixed level of spending affects the current account is mixed.

Rosenzweig and Tallman (1993) argue that these inconclusive results stem from data differences and the choice of empirical technique. Feldstein (1992), however, provides an alternative explanation, based on national accounting identities. A rise in the fiscal deficit will result in a fall in national saving (unless it is fully offset by a rise in private saving). Lower national saving must produce an offsetting reduction in the sum of investment and net exports, but the split between them depends on a range of factors, such as the interest sensitivity of investment and trade, and structural determinants of investment, trade, and capital flows. Hence, in the United States in the early 1980 s, the conjunction of the various factors meant that the fiscal expansion had a larger impact on the current account than on investment; ${ }^{40}$ but, at other times and in other countries, different conditions could apply, changing the relationship between the fiscal and trade deficits.

\section{Tests of Ricardian equivalence}

Many empirical studies provide indirect tests of Ricardian equivalence by assessing whether the strong assumptions required for full Ricardian equivalence to hold are empirically valid. Indirect tests strongly reject full Ricardian equivalence (Barro, 1989, and Seater, 1993), but the behavior of private consumption may still be consistent with a partial Ricardian offset. However, the evidence from direct tests of Ricardian equivalence is very mixed, and no clear conclusions have emerged about the existence and size of the Ricardian offset (see Bernheim, 1989, and Barro, 1989, for opposing interpretations of the empirical evidence). A key difficulty stems from the fact that estimation results are very sensitive to measurement and methodological issues. In particular, misspecification, omitted variables, or endogeneity problems may lead to biased estimates of some coefficients, ${ }^{41}$ and results also appear to be very sensitive to the treatment of nonstationarity (i.e., whether equations are estimated in level or first difference form). In addition, as noted by Leiderman and Blejer (1988), even in a Ricardian world the impact of debt-financed tax cuts depends in part on the signal they send about future government spending and taxation. Few studies explicitly take into account

\footnotetext{
${ }^{40}$ Feldstein cites tax reforms which encouraged investment, and structural factors reducing the demand for U.S. exports, such as the Latin American debt crisis and the growth of electronics exports from South East Asia.

${ }^{41}$ In particular, omitting government spending-which affects permanent income even in a Ricardian modelfrom the estimated consumption function may lead to an overestimation of the coefficients on other government variables.
} 
this signaling process (although some studies distinguish between permanent and temporary changes in government spending, for example, Seater and Mariano, 1985).

Most studies provide estimates of the marginal propensity to consume out of tax cuts that are in the range of $0.2-0.5$ (see Bernheim, 1989 and Boskin, 1988 for surveys), although Hubbard and Judd (1986) point out that such results are very sensitive to the estimated proportion of liquidity-constrained consumers. In a model where deviations from Ricardian equivalence arise from uncertainty about future income, Barsky, Mankiw, and Zeldes (1986) obtain (by simulation) marginal propensities to consume out of tax cuts of 0.3 to $0.5 .^{42}$

Most of the empirical evidence on Ricardian equivalence relates to the United States. But cross-country studies also fail to reach clear conclusions. Using data from 26 countries (including some developing countries), Bernheim (1987) estimates a range of different consumption equations and concludes that fiscal deficits stimulate private consumption, with an estimated marginal propensity to consume in the range of $0.3-0.5$. Masson, Bayoumi, and Samiei (1995) find similar results using data from 21 advanced economies, ${ }^{43}$ while Giavazzi, Japelli, and Pagano (2000) reject Ricardian equivalence for a panel of 18 OECD countries. But Evans (1991) estimates consumption equations for 19 countries and fails to reject Ricardian equivalence in 18 cases. Callen and Thimann (1997) examine 21 advanced economies. Their cross-section estimates suggest a larger response of private saving to changes in public saving than is generally found in time-series studies. However, the offsets are much smaller when panel estimation techniques are used.

\section{Tests of consumption smoothing}

A number of studies address whether consumption is smoothed despite variations in disposable income. The literature for the United States is summarized in Seidman (2001). Campbell and Mankiw (1989) find that households can be divided into two halves by total income, one which consumes according to current income and one which consumes according to permanent income. Analyses of the impact of changes in withholding taxes (Shapiro and Slemrod, 1995), of changes in social security taxes (Parker, 1999) and of income tax refunds (Souleles, 1999) produce qualitatively similar results.

\footnotetext{
${ }^{42}$ If the marginal propensity to consume is usually 0.8 , a marginal propensity to consume out of tax cuts in this range implies a Ricardian offset (i.e., the response of private saving to a change in public saving) in the range of $0.4-0.6$.

${ }^{43}$ Masson, Bayoumi, and Samiei (1995) also find that the Ricardian offset is around 50 percent for changes in taxes and government investment, but only around 10 percent for changes in current spending, implying that the latter will tend to have a larger output effect in the short term. But temporary changes in government spending do not appear to have larger short-term output effects than permanent changes.
} 


\section{Other factors influencing fiscal multipliers}

Direct crowding out. A number of studies have estimated the extent to which government spending substitutes for private consumption, and have found direct crowding out coefficients in the range $0-0.4,{ }^{44}$ although they tend not to be very robust. In one such study, Darby and Malley (1996) allow the direct crowding out coefficient to vary over time, reflecting changes in the composition of spending between defense, federal nondefense, and state/local components, and derive more robust estimates in much the same range.

Price flexibility. Koelln, Rush, and Waldo (1996) use data from 35 countries to test the link between price stickiness and the size of fiscal (and monetary) policy multipliers. Since the degree of price stickiness is not directly observable, they assume that prices are more flexible in high inflation economies. ${ }^{45}$ They then use a two-step procedure, first deriving estimates of fiscal and monetary policy multipliers from simple reduced-form output equations, and then examining the relationship between these estimates and various measures of average inflation. They fail to find any relationship between inflation (and hence the degree of price flexibility) and the size of policy multipliers. It should be noted, however, that this finding contrasts with those of Ball, Mankiw, and Romer (1988) and DeFina (1991), who conclude that the impact of a change in aggregate demand (without distinguishing between the effects of monetary and fiscal policy) on output is inversely related to the degree of price flexibility.

Lags. In a study of postwar U.S. recessions, Romer and Romer (1994) suggest that the evidence supports the view that only limited fiscal stimulus can be provided rapidly. Bartlett (1993) is even more pessimistic, although he focuses on public works programs rather than the full range of fiscal actions that have been undertaken to end recessions. Moreover, Romer and Romer (1994) note that rapid fiscal changes have been both small in size and restricted to those where congressional approval is not required or easy to obtain. They find no examples of major legislated spending changes in response to recessions, and only two major tax cuts (in 1953 and 1975) which were in response to recessions. ${ }^{46}$

In Section II, it was noted that automatic stabilizers would be relatively more effective in the presence of lags. Most empirical studies of the impact of fiscal policy on economic activity do not distinguish between automatic stabilizers and discretionary actions since there should be no difference between the multiplier associated with each. But OECD (1999) is an exception, and one finding of this study is that discretionary fiscal policy has a larger effect on output than automatic stabilizers. In the United States and Japan, discretionary fiscal policy and automatic stabilizers operate in the same direction, but in the euro area they have

\footnotetext{
${ }^{44}$ Such studies include Feldstein (1982); Kormendi (1983); Aschauer (1985); Bean (1986); and Graham (1993).

${ }^{45}$ This assumption is based on a result established by Ball, Mankiw, and Romer (1988).

${ }^{46}$ Other major tax cuts during the postwar period have been in response to growth slowdowns rather than recessions.
} 
offsetting effects. However, the question about which type of fiscal policy change has the greater impact on activity for a given change in the deficit is not asked.

\section{B. Developing Countries}

Due to a combination of data deficiencies, and the structural/institutional factors mentioned in Section II, there is much less evidence on the short-term effects of fiscal policy on economic activity for developing countries than for advanced economies. Such evidence as there is covers estimates of fiscal multipliers, the relationship between fiscal deficits, interest rates and investment, and tests of Ricardian equivalence.

\section{Estimates of fiscal multipliers}

While a number of studies have analyzed the effects of fiscal policy on long-term growth rates in developing countries, ${ }^{47}$ one recent study - Gupta, and others (2002)-has specifically examined the impact of fiscal adjustment and expenditure composition on growth in the short term. Using data on a sample of 39 low-income countries over the period 1990-2000, they conclude that: (1) a 1 percentage point reduction in the deficit-to-GDP ratio results in an average increase in per capita real growth of $1 / 4$ to $1 / 2$ percent in the short run;

(2) consolidation based on cuts in current expenditure has a bigger growth impact than those based on revenue increases and cuts in capital spending; (3) adjustments resulting in a reduction in domestic financing have around $1 \frac{1 / 2}{2}$ times the effect on growth as those based on reductions in external and domestic financing; and (4) in those low income countries that have achieved fiscal and macro stability, more typical Keynesian effects of fiscal policy predominate.

There are some studies that attempt to estimate macroeconomic models for developing economies to quantify the impact of different shocks to the economy. While remaining sensitive to the underlying assumptions, these models provide some insight about fiscal multipliers in developing countries. However, no clear conclusions emerge about the size and sign of fiscal multipliers.

- Haque and Montiel (1991) estimate a dynamic, small open economy

Mundell-Fleming model incorporating rational expectations and full employment for a sample of 31 developing countries, and then simulate a government spending shock taking the form of increased purchases of domestic goods. Given price flexibility, the increase in demand automatically feeds through to higher prices. It is concluded that the short- and medium-term effects of increased government spending are contractionary, while there is no long-term effect. The dynamic path of output is

\footnotetext{
${ }^{47}$ See, for example, Landau (1986), Easterly and Rebelo (1993), and Adam and Bevan (2001). Many other studies analyze a combined sample of developed, developing, and middle income countries; see Kneller, Bleaney, and Gemmell (1998).
} 
governed by the behavior of real interest rates; the initial rise in interest rates crowds out output, which then returns gradually to its steady-state level.

- Haque, Montiel, and Symansky (1991) develop a general-equilibrium simulation model incorporating rational expectations. Representative developing country parameters are used to conduct simulation experiments, one of which involves a temporary increase in government spending, financed by external borrowing. Although output falls initially (due to crowding out), both output and inflation rise in subsequent periods. With external financing and an assumption of no sterilization, the fiscal expansion is bolstered by monetary expansion, and lower interest rates spur investment. Hence the financing assumption is crucial for determining the effects of such a shock. The dynamic adjustment process also tends to be sensitive to the assumptions made about expectations.

- Khan and Knight (1981) use data from 29 developing countries in an attempt to quantify the relationship between the deviation of output from potential and policy variables in the context of a modified monetary model in which inflation and output are both endogenous. The nominal income elasticities of government spending and taxes are positive and close to unity.

Kandil (1991) argues that spending multipliers are larger in developing countries than in industrial countries. Using data for 21 developing and 18 developed countries, both the marginal propensity to consume and the marginal propensity to invest are estimated; in each case, they are larger for developing countries. While the interest elasticity of money demand is shown to be lower in developing countries, there is no effective difference in the income elasticity of money demand. Accordingly, monetary policy is more effective than fiscal policy for demand management. Owoye, Nyatepe-Coo, and Onafowora (1995) also confirm that monetary policy is more influential in affecting output than fiscal policy in a study of eight Asian countries.

\section{Determinants of crowding out}

Agénor and Montiel (1996) examine the relationship between fiscal deficits and real interest rates in eight middle-income developing countries. They find that in some countries (Brazil, Korea, and Thailand) there is a positive relationship between deficits and real interest rates, while in other countries the relationship is weak. They speculate that a weak relationship may be due to controls on interest rates or to expectations about future fiscal policy. Easterly, Rodriguez, and Schmidt-Hebbel (1994) find that, in a large sample of developing countries, fiscal deficits tend to result in low real interest rates. They rationalize this perverse result by reference to the association between financial repression and loose fiscal policies.

While interest rates may be positively related to fiscal expansion, the extent of crowding out will also depend on the relationship between interest rates and investment. In principle, the interest elasticity of investment could be positive in developing countries. This would be the case if investors are credit constrained, and need to accumulate money balances before they 
can undertake investment, while money balances are positively related to real deposit rates. Thus Blejer and Khan (1984) suggest that the principal impediment to investment in developing countries is the quantity and not the cost of financing. The empirical evidence generally confirms that, as in the advanced economies, the interest elasticity of investment is negative but small, suggesting that crowding out through interest rates is weak. Rama (1993) synthesizes 31 empirical studies of the determinants of investment in developing countries. He finds that in the studies where the cost of capital is measured appropriately, it usually has the expected negative coefficient but is often insignificant. Using a sample of ten developing countries in the 1980s, Easterly, Rodriguez, and Schmidt-Hebbel (1994) find that high interest rates have only a small negative effect on investment. Despite finding larger fiscal multipliers in developing countries than advanced economies, Kandil (1991) somewhat surprisingly finds evidence of a large negative interest elasticity of investment in some developing countries as well. This impact, however, is far outweighed by large marginal propensities to consume and invest.

\section{Tests of Ricardian equivalence}

It could be argued that the conditions required for Ricardian equivalence to hold are even less likely to be satisfied in developing countries than in advanced economies. Agénor and Montiel (1996) note that, in developing countries, financial systems are underdeveloped, capital markets tend to be highly distorted and subject to repression, and consumers are subject to considerable uncertainty about the incidence of taxes. On the other hand, Ricardian logic may be more relevant in periods of crisis, rather than over standard business cycles (Sutherland, 1997). To the extent that this is the case, Ricardian equivalence could possibly be more applicable to developing countries.

Studies that have attempted to determine the extent of liquidity constraints tend to suggest that Ricardian equivalence does not hold in developing countries. Haque and Montiel (1989) estimate consumption functions for 16 developing countries. They find that a high proportion of consumers are liquidity constrained in developing countries; the estimates range from 18 percent of households in Korea to 70 percent in Thailand, with an average of around 40 percent. This is substantially higher than equivalent estimates for advanced economies (for the United States, Germany, and Japan, the range is 10 to 30 percent). Reflecting these liquidity constraints, Ricardian equivalence is judged inapplicable in 14 of the 16 countries in the sample. Khalid (1996) finds more mixed results, but also points to liquidity constraints as the key culprit in rejecting Ricardian equivalence. Using data from 31 developing countries, Haque, Lahiri, and Montiel (1990) estimate a flex price Mundell-Fleming model, from which they find that current disposable income affects consumption; they conclude that 15 percent of consumers face liquidity constraints. In a follow-up study, Haque, Lahiri, and Montiel (1993) estimate a similar macroeconomic model for the same sample, allowing for capital controls and the effects of financial repression, and then conclude that about one-third of consumers are liquidity constrained.

While Masson, Bayoumi, and Samiei (1995) reject full Ricardian equivalence for all but a high-income subgroup of 40 developing countries, there is evidence of a partial Ricardian 
offset. On average, they find that a change in private sector saving offsets 63 percent of a change in taxes. Cuts in government current spending have the same effect as taxes, but there is a smaller offset for cuts in public investment, of around 40 percent.

Corbo and Schmidt-Hebbel (1991) also provide evidence from a sample of 13 developing countries consistent with a partial Ricardian offset. They find that a temporary increase in public saving brought about by cutting spending leads to a reduction in private saving by 16 percent to 50 percent. In contrast, an equivalent increase in public saving brought about by raising taxes leads to a 48 percent to 65 percent reduction in private saving. However, results from 10 case studies analyzed by Easterly, Rodriguez, and Schmidt-Hebbel (1994) are less clear, since in only three countries (Argentina, Morocco, and Zimbabwe) has an increase in public saving led to lower private saving.

Finally, Giavazzi, Jappelli, and Pagano (2000) analyze the determinants of national savings in 101 developing countries, drawn from a World Bank data set covering 1960-95, and reject Ricardian equivalence. They also find some evidence that large fiscal consolidations result in lower saving, which is consistent with the findings from expansionary fiscal contractions in OECD countries, although the authors note that data deficiencies make these findings for developing countries less robust than those for advanced economies.

\section{SUMmary AND CONCLUSIONS}

The theoretical literature on the effectiveness of fiscal policy spans the simple Keynesian model, closed and open economy IS-LM models, demand-side models incorporating rational expectations, Ricardian equivalence, interest rate premiums and credibility, and uncertainty, and supply-side (including new classical) models. This literature suggests that fiscal multipliers will tend to be positive and possibly quite large when:

- There is excess capacity, the economy is either closed or it is open and the exchange rate is fixed, and households have limited time horizons or are liquidity constrained.

- Increased government spending does not substitute for private spending, it enhances the productivity of labor and capital, and lower taxes increase labor supply and/or investment.

- Government debt is low and the government does not face financing constraints.

- There is an accompanying monetary expansion with limited inflationary consequences.

Fiscal multipliers are likely to be smaller, and could turn negative, when: 
- There is crowding out either directly as government provision substitutes for private provision and through imports, or as interest rates rise and a flexible exchange rate appreciates in response to a fiscal expansion.

- Households are Ricardian, in which case a permanent fiscal expansion can reduce consumption.

- There is a debt sustainability problem and risk premia on interest rates are large, in which case a credible fiscal contraction can result in a large fall in interest rates.

- $\quad$ Expansionary fiscal policy increases uncertainty which leads to more cautious saving and investment decisions by households and firms.

The empirical literature has three substantive components. First, there are estimates of fiscal multipliers derived from macroeconomic model simulations and reduced-form equations. Second, there are studies that draw lessons by looking across episodes of fiscal adjustment, with a special emphasis on identifying expansionary fiscal contractions. Third, some studies look at factors that influence fiscal multipliers, focusing on the evidence to support crowding out and Ricardian equivalence. Nearly all the available empirical literature relates to OECD countries, indeed much of it concentrates on the United States, Japan and major European countries. The main conclusions are as follows:

- $\quad$ Estimates of fiscal multipliers are overwhelmingly positive but small. Short-term multipliers average around a half for taxes and one for spending, with only modest variation across countries and models (albeit with some outliers). There are hardly any instances of negative fiscal multipliers, the exception being that they can be generated in some macroeconomic models with strong credibility effects.

- There is nevertheless evidence of non-Keynesian expansionary fiscal contractions. The most frequently cited examples are Denmark (1983-86) and Ireland (1987-89). Expansionary fiscal contractions appear to be more likely where a fiscal contraction is large and focuses on cuts in unproductive spending; occurs against a background of high debt which leads to sizable risk premia on interest rates; is accompanied by a significant depreciation and wage restraint; and increases the credibility of fiscal policy.

There is little evidence of direct crowding out or crowding out through interest rates and the exchange rate. Nor does full Ricardian equivalence or a significant partial Ricardian offset get much support from the evidence.

The implications of the theoretical and empirical literature for fiscal policy advice are as follows. The proper fiscal policy response to a downturn in the economy will depend on a range of factors, and only a country-by-country approach, and indeed an episode-by-episode approach, can reveal whether a fiscal expansion or a fiscal contraction is appropriate. In this connection, the key questions to ask are the following: 
- What is the source of a downturn in economic activity? Fiscal policy will be more effective if output is constrained on the demand side, in which case the presumption should be that a fiscal expansion is appropriate.

- How responsive are interest rates, the exchange rate, and prices to a fiscal expansion? This will determine the extent of crowding out, and therefore whether fiscal multipliers are fairly large or fairly small.

- Are accompanying policies supportive? An accompanying monetary expansion will limit crowding out through interest rates and the exchange rate.

- Is a fiscal expansion likely to be permanent and is government debt sustainable? This will influence whether a fiscal expansion could lead to higher risk premia and increase uncertainty, in which case a fiscal contraction may be appropriate.

- What is the composition of a fiscal expansion or contraction? Increases in spending tend to be associated with larger fiscal multipliers that tax cuts. Moreover, spending and tax measures that have desirable supply-side effects may have beneficial short-term consequences via expectations. The distinction between productive and unproductive spending may also matter. In particular, cuts in unproductive spending, especially transfers, are more likely to result in expansionary fiscal contractions.

- $\quad$ Finally, what influences the behavior of households and firms? This is perhaps the most difficult judgment to make, but the way in which saving and investment respond to a fiscal expansion or contraction can be significantly influenced by factors such as liquidity constraints, the way expectations are formed, and consumer and investor confidence. 


\section{References}

Adam, Christopher S., and David L. Bevan, 2001, "Nonlinear Effects of Public Deficits on Growth," paper presented at a Cornell/ISPE Conference, New York, September.

Agénor, Pierre-Richard, C. John McDermott, and Eswar S. Prasad, 1999, "Macroeconomic Fluctuations in Developing Countries: Some Stylized Facts," IMF Working Paper 99/35 (Washington: International Monetary Fund).

Agénor, Pierre-Richard, and Peter J. Montiel, 1996, Development Macroeconomics (Princeton, New Jersey: Princeton University Press).

Ahmed, Shaghil, 1986, "Temporary and Permanent Government Spending in an Open Economy," Journal of Monetary Economics, Vol. 17, pp. 197-224.

Aiyagari, S. Rao, Lawrence J. Christiano, and Martin Eichenbaum, 1992, "The Output, Employment, and Interest Rate Effects of Government Consumption," Journal of Monetary Economics, Vol. 30 (July), pp. 73-86.

Alesina, Alberto, and Roberto Perotti, 1995, "The Political Economy of Budget Deficits," Staff Papers, International Monetary Fund, Vol. 42 (March), pp. 1-31.

— 1997, "Fiscal Adjustments in OECD Countries: Composition and Macroeconomic Effects," IMF Working Paper 96/70 (Washington: International Monetary Fund).

_ José Tavares, 1998, "The Political Economy of Fiscal Adjustments," Brookings Papers on Economic Activity: 1, Brookings Institution, pp. 197-266.

Alesina, Alberto, and Silvia Ardagna, 1998, "Tales of Fiscal Adjustment," Economic Policy: A European Forum, Vol. 27 (October), pp. 487--546.

—. Roberto Perotti, and Fabio Schiantarelli, 2002, "Fiscal Policy, Profits and Investment," American Economic Review, Vol. 92, No. 3, pp. 571-89.

Ardagna, Silvia, 2001, "Fiscal Policy Composition, Public Debt, and Economic Activity" Public Choice, Vol. 109, pp. 301-325.

Aschauer, David Alan, 1985, "Fiscal Policy and Aggregate Demand," American Economic Review, Vol. 75 (March), pp.117-27.

Auerbach, Alan J., and Laurence J. Kotlikoff, 1987, Dynamic Fiscal Policy (New York: Cambridge University Press).

Azariadis, Costas, and Allan Drazen, 1990, "Threshold Externalities in Economic Development," Quarterly Journal of Economics, Vol. 105 (May), pp. 501-26. 
Ball, Laurence, N. Gregory Mankiw, and David Romer, 1988, "The New Keynesian Economics and the Output-Inflation Tradeoff," Brookings Papers on Economic Activity: 1, Brookings Institution, pp. 1-82.

Barrell, Ray, Sylvia Gottschalk, Ian Hurst, and Desiree van Welsum, 2002, "Macroeconomic Policy in Europe-Experiments with Monetary Responses, Fiscal Impulses and Labour Market Innovations" (London: National Institute of Economic and Social Research).

Barro, Robert J., 1974, “Are Government Bonds Net Wealth?” Journal of Political Economy, Vol. 82 (November-December), pp. 1095-1117.

- 1981, "Output Effects of Government Purchases," Journal of Political Economy, Vol. 89 (December), pp. 1086-1121.

_- 1989, "The Ricardian Approach to Budget Deficits," Journal of Economic Perspectives, Vol. 3 (Spring), pp. 37-54.

_- 1992, "World Interest Rates and Investment," Scandinavian Journal of Economics, Vol. 94, No. 2, pp. 323-42.

— Macroeconomics Annual 1990, ed. by Olivier J. Blanchard and Stanley Fischer (Cambridge, Massachusetts: MIT Press).

Barry, Frank, and Michael B. Devereux, 1994, "The Macroeconomics of Government Budget Cuts: Can Fiscal Contractions be Expansionary?" in Deficit Reduction-What Pain, What Gain?, ed. by William B.P. Robson and William M. Scarth (Toronto: C.D. Howe Institute).

Barsky, Robert B., N. Gregory Mankiw, and Stephen P. Zeldes, 1986, "Ricardian Consumers with Keynesian Propensities," American Economic Review, Vol. 76 (September), pp. 676-91.

Bartlett, Bruce, 1993, "How Not to Stimulate the Economy," The Public Interest, No. 112 (Summer), pp. 99-109.

Bartolini, Leonardo, Assaf Razin, and Steven Symansky, 1995, "G-7 Fiscal Restructuring in the 1990s: Macroeconomic Effects," Economic Policy, No. 20 (April), pp.111-46.

Baxter, Marianne, and Robert G. King, 1993, "Fiscal Policy in General Equilibrium," American Economic Review, Vol. 83 (June), pp. 315-34. 
Bayoumi, Tamim, 2000, "The Morning After: Explaining the Slowdown in Japanese Growth," in Post-Bubble Blues-How Japan Responded to Asset Price Collapse, ed. by Tamim Bayoumi and Charles Collyns (Washington: International Monetary Fund).

— and Douglas Laxton, 1994, "Government Deficits, Debt, and the Business Cycle," in Deficit Reduction-What Pain, What Gain?, ed. by William B.P. Robson and William M. Scarth (Toronto: C.D. Howe Institute).

Bean, Charles R., 1986, "The Estimation of 'Surprise' Models and the 'Surprise' Consumption Function," Review of Economic Studies, Vol. 53 (August), pp. 497-516.

Beck, Stacie E., 1993, "Ricardian Equivalence Proposition: Evidence from Foreign Exchange Markets," Journal of International Money and Finance, Vol. 12 (May), pp. 154-69.

Bernheim, B. Douglas, 1987, "Ricardian Equivalence: An Evaluation of Theory and Evidence," in NBER Macroeconomics Annual 1987, ed. by Stanley Fischer (Cambridge, Massachusetts: MIT Press).

— 1988, "Budget Deficits and the Balance of Trade," Tax Policy and the Economy (Cambridge, Massachusetts: MIT Press).

—_. 1989, "A Neoclassical Perspective on Budget Deficits," Journal of Economic Perspectives, Vol. 3 (Spring), pp. 55-72.

Bertola, Giuseppe, and Allan Drazen, 1993, "Trigger Points and Budget Cuts: Explaining the Effects of Fiscal Austerity," American Economic Review, Vol. 83 (March), pp. 11-26.

Blanchard, Olivier Jean, 1985, "Debt, Deficits, and Finite Horizons," Journal of Political Economy, Vol. 93 (April), pp. 223-47.

_ 1986, "Empirical Structural Evidence on Wages, Prices and Employment in the U.S.," NBER Working Paper No. 2044 (Cambridge, Massachusetts: National Bureau of Economic Research).

—_ 1990, "Comment on 'Can Severe Fiscal Contractions be Expansionary'?" in NBER Macroeconomics Annual 1990, ed. by Olivier J. Blanchard and Stanley Fischer (Cambridge, Massachusetts: MIT Press).

___-, 1997, "Is There a Core of Usable Macroeconomics?" American Economic Review, Papers and Proceedings, Vol. 87 (May), pp. 244-46. 
, and Lawrence H. Summers, 1984, "Perspectives on High World Real Interest Rates," Brookings Papers on Economic Activity: 2, Brookings Institution, pp. 273-324.

, and Roberto Perotti, 2002, "An Empirical Characterization of the Dynamic Effects of Changes in Government Spending and Taxes on Output," Quarterly Journal of Economics (forthcoming).

Blejer, Mario I., and Mohsin S. Khan, 1984, "Government Policy and Private Investment in Developing Countries," Staff Papers, International Monetary Fund, Vol. 31 (June), pp. 379-403.

Blinder, Alan S., and Robert M. Solow, 1974, "Analytical Foundations of Fiscal Policy," in The Economics of Public Finance: Essays, ed. by Alan S. Blinder and others (Washington: Brookings Institution).

Blundell, Richard, and Thomas MaCurdy, 1999, Vol. 3A, "Labor Supply: A Review of Alternative Approaches," in Handbook of Labor Economics, ed. by Orly Ashenfelter and David Card (Amsterdam; New York: Elsevier).

Boskin, Michael J., 1988, "Consumption, Savings, and Fiscal Policy," American Economic Review, Papers and Proceedings, Vol. 78 (May), pp. 401-407.

Bruneau, Catherine, and Olivier de Bandt, 1999, "Fiscal Policy in the Transition to Monetary Union: A Structural VAR Model," Les Notes d'Études et de Recherche (NER) (Paris: Banque de France).

Brunner, Allan D., and Graciela L. Kaminsky, 1994, "World Interest Rates: Do Fiscal and Monetary Policies Matter After All?" (unpublished; Washington: Federal Reserve System).

Bryant, Ralph C., Dale W. Henderson, Gerald Holtham, Peter Hooper, and Steven Symansky, eds., 1988, Empirical Macroeconomics for Interdependent Economies (Washington: Brookings Institution).

Bryant, Ralph C., Peter Hooper, and Catherine L. Mann, eds., 1993, Evaluating policy Regimes: New Research in Empirical Macroeconomics (Washington: Brookings Institution).

Caballero, Ricardo J., and Robert S. Pyndick, 1996, "Uncertainty, Investment, and Industry Evolution," International Economic Review, Vol. 37 (August), pp. 641-62.

Callen, Tim, and Christian Thimann, 1997, "Empirical Determinants of Household Saving: Evidence from OECD Countries," IMF Working Paper 97/181 (Washington: International Monetary Fund). 
Campbell, John Y., and N. Gregory Mankiw, 1989, "Consumption, Income, and Interest Rates: Reinterpreting the Time Series Evidence," in NBER Macroeconomics Annual, ed. by Olivier J. Blanchard and Stanley Fischer (Cambridge, Massachusetts: MIT Press).

Caramazza, Francesco, 1993, "French-German Interest Rate Differentials and Time-Varying Realignment Risk," Staff Papers, International Monetary Fund, Vol. 40 (September), pp. 567-83.

Catinat, M. Cawley, Fabienne Ilzkovitz, Alexander Italianer, and Matthias Mors, 1987, "Determinants of Investment," European Economy/Commission of the European Communities (International), No. 31 (March), pp. 5-60.

Chari, V.V., and Patrick J. Kehoe, 1998, "Optimal Fiscal and Monetary Policy," Federal Reserve Bank of Minneapolis, Research Department Staff Report No. 251 (Minneapolis: Federal Reserve Bank of Minneapolis).

Chen, Zhaohui, and Alberto Giovannini, 1993, "Determinants of Realignment Expectations Under the EMS: Some Empirical Regularities," NBER Working Paper No. 4291 (Cambridge, Massachusetts: National Bureau of Economic Research).

Chirinko, Robert S., 1993, "Business Fixed Investment Spending: Modeling Strategies, Empirical Results and Policy Implications," Journal of Economic Literature, Vol. 31 (December), pp. 1875-1911.

Clark, Peter K., 1979, "Investment in the 1970s: Theory, Performance and Prediction," Brookings Papers on Economic Activity: 1, Brookings Institution, pp. 73-124.

Corbo, Vittorio, and Klaus Schmidt-Hebbel, 1991, "Public Policies and Saving in Developing Countries," Journal of Development Economics, Vol. 36, (July), pp. 89-115.

Cotis, Jean-Phillipe, Yannick L'Horty, and Renaud Meary, 1998, "Les Stabilisateurs Automatiques sont-ils Encore Efficaces: Le Cas de la France dans les Annees Quatre-vingt-dix," Revue d'Economie Financière, Vol. 45, pp. 95-118.

Cour, Philippine, Eric Dubois, Selma Mahfouz, and Jean Pisani-Ferry, 1996, "The Cost of Fiscal Retrenchment Revisited: How Strong is the Evidence?" Institut National de la Statistique et des Etudes Economiques, Série des Documents de Travail G9612 (Paris).

Dalsgaard, Thomas, Christophe André, and Pete Richardson, 2001, "Standard Shocks in the OECD Interlink Model," OECD Working Paper 306 (Paris: Organization for Economic Cooperation and Development). 
Darby, Julia, and Jim Malley, 1996, "Fiscal Policy and Consumption: New Evidence from the United States," Scottish Journal of Political Economy, Vol. 43 (May), pp. 129-45.

De Fina, Robert H., 1991, "International Evidence on a New Keynesian Theory of the Output-Inflation Trade-Off," Journal of Money, Credit, and Banking, Vol. 23 (August), pp. 410-22.

Devereux, Michael B., Allen C. Head, and Beverly J. Lapham, 1996, "Monopolistic Competition, Increasing Returns, and the Effects of Government Spending," Journal of Money, Credit, and Banking, Vol. 28, No. 2, pp. 233-54.

Dewald, William G., and Michael Ulan, 1990, "Twin-Deficit Illusion," Cato Journal (Winter), pp. 689-707.

Dotsey, Michael, 1994, "Some Unpleasant Supply Side Arithmetic," Journal of Monetary Economics, Vol. 33 (June), pp. 507-24.

Drazen, Allan, 1990, "Comment on "Can Severe Fiscal Contractions be Expansionary'?" in NBER Macroeconomics Annual 1990, ed. by Olivier J. Blanchard and Stanley Fischer (Cambridge, Massachusetts: MIT Press).

Easterly, William, and Sergio Rebelo, 1993, "Fiscal Policy and Economic Growth: An Empirical Investigation," NBER Working Paper No. 4499 (Cambridge, Massachusetts: National Bureau of Economic Research).

Easterly, William, Carlos Rodriguez, and Klaus Schmidt-Hebbel, 1994, Public Sector Deficits and Macroeconomic Performance (New York: Oxford University Press).

Edelberg, Wendy, Martin Eichenbaum, and Jonas D.M. Fisher, 1999, "Understanding the Effects of a Shock to Government Purchases," Review of Economic Dynamics, Vol. 1 (January), pp. 166-206.

Eichengreen, Barry, 1998, "Comment on 'The Political Economy of Fiscal Adjustments'," Brookings Papers on Economic Activity: 1, Brookings Institution, pp. 255-62.

Eisner, Robert, 1989, "Budget Deficits: Rhetoric and Reality," Joumal of Economic Perspectives, Vol. 3 (Spring), pp. 73-93.

Enders, Walter, and Bong-Soo Lee, 1990, "Current Account and Budget Deficits: Twins or Distant Cousins?" Review of Economics and Statistics (August), pp. 373-81.

Evans, George, 1985, "Bottlenecks and the Phillips Curve: A Disaggregated Keynesian Model of Inflation, Output, and Unemployment," Economic Journal, Vol. 95 (June), pp. $345-57$. 
, 1986, "Test for Speculative Bubbles in the Sterling-Dollar Exchange Rate: 1981-84," American Economic Review, Vol. 76 (September), pp. 621-36.

Evans, Martin, 1991, "Discovering the Link Between Inflation Rates and Inflation Uncertainty," Journal of Money, Credit, and Banking, Vol. 23 (May), pp. 169-84.

Evans, Paul, 1987, "Do Budget Deficits Raise Nominal Interest Rates? Evidence from Six Countries," Journal of Monetary Economics, Vol. 20 (September), pp. 281-300.

—_ 1989, "Do Budget Deficits Affect the Current Account?" Working Paper, Ohio State University.

Fatás, Antonio, and Ilian Mihov, 2001, "The Effects of Fiscal Policy on Consumption and Employment: Theory and Evidence," CEPR Discussion Paper No. 2760 (London: Centre for Economic Policy Research).

Fazzari, Steven M., 1994, "Why Doubt the Effectiveness of Keynesian Fiscal Policy?" Journal of Post Keynesian Economics (Winter), pp. 231-48.

Feldstein, Martin S., 1982, "Government Deficits and Aggregate Demand," Journal of Monetary Economics, Vol. 9 (January), pp.1-20.

— 1986, "The Budget Deficit and the Dollar," in NBER Macroeconomics 1986, ed. by Stanley Fischer (Cambridge, Massachusetts: MTT Press).

,1992, "The Budget and Trade Deficits Aren't Really Twins," NBER Working Paper No. 3966 (Cambridge, Massachusetts: National Bureau of Economic Research).

Finn, Mary G., 1998, “Cyclical Effects of Government's Employment and Goods Purchases," International Economic Review, Vol. 39, No. 3, pp. 635-56.

Ford, Robert, and Douglas Laxton, 1995 "World Public Debt and Real Interest Rates," IMF Working Paper 95/30 (Washington: International Monetary Fund).

Ford, Robert, and P. Poret, 1990, "Business Investment in the OECD Economies: Recent Performance and Some Implications for Policy," OECD Working Paper No. 88 (Paris: Organization for Economic Cooperation and Development).

Giavazzi, Francesco, Tullio Jappelli, and Marco Pagano, 2000, "Searching for Non-Linear Effects of Fiscal Policy: Evidence from Industrial and Developing Countries," NBER Working Paper No. 7460 (Cambridge, Massachusetts: National Bureau of Economic Research). 
Giavazzi, Francesco, and Marco Pagano, 1990, "Can Severe Fiscal Contractions be Expansionary? Tales of Two Small European Countries" in NBER Macroeconomics Annual 1990, ed. by Olivier J. Blanchard and Stanley Fischer (Cambridge, Massachusetts: MIT Press).

_ 1996, "Non-Keynesian Effects of Fiscal Policy Changes: International Evidence and the Swedish Experience," Swedish Economic Policy Review, Vol. 3, pp. 67-103.

Gali, Jordi, 1998, "Comment on Tales of Fiscal Adjustment," Economic Policy, Vol. 27, pp. 518-20.

Goldfeld, Stephen M., and Daniel E. Sichel, 1990, "The Demand for Money," in Handbook of Monetary Economics, Vol. 1, ed. by Benjamin M. Friedman and Frank H. Hahn (Amsterdam, New York: North-Holland), pp. 299-356.

Graham, Fred C., 1993, "Fiscal Policy and Aggregate Demand: Comment," American Economic Review, Vol. 83 (June), pp. 659-66.

Gupta, Sanjeev, Benedict Clements, Emanuele Baldacci, and Carlos Mulas-Granados, 2002, "Expenditure Composition, Fiscal Adjustment, and Growth in Low-Income Countries," IMF Working Paper 02/77 (Washington: International Monetary Fund).

Hall, Robert E., 1980, "Labor Supply and Aggregate Fluctuations," Carnegie-Rochester Conference Series on Public Policy (New York; Amsterdam: North-Holland).

Haque, Nadeem U., Kajal Lahiri, and Peter Montiel, 1990, "An Econometric Rational-Expectations, A Macroeconomic Model for Developing Countries with Capital Controls," IMF Working Paper 90/11 (Washington: International Monetary Fund).

1993, "Estimation of a Macroeconomic Model with Rational Expectations and Capital Controls for Developing Countries," Journal of Development Economics, Vol. 42, (December), pp. 337-56.

Haque, Nadeem U., and Peter J. Montiel, 1989, "Consumption in Developing Countries: Test for Liquidity Constraints and Finite Horizons," Review of Economics and Statistics, Vol. 71 (August), pp. 408-15.

— 1991, "Dynamic Responses to Policy and Exogenous Shocks in an Empirical Developing Country Model with Rational Expectations," in Macroeconomic Models for Adjustment in Developing Countries, ed. by Mohsin S. Khan, Peter J. Montiel, and Nadeem U. Haque (Washington: International Monetary Fund). 
, and Steven A. Symansky, 1991, "A Forward Looking Macroeconomic Simulation Model for a Developing Country," in Macroeconomic Models for Adjustment in Developing Countries, ed. by Mohsin S. Khan, Peter J. Montiel, and Nadeem U. Haque (Washington: International Monetary Fund).

Helbling, Thomas, and Robert Wescott, 1995, "The Global Real Interest Rate," Staff Studies for the World Economic Outlook, (September) (Washington: International Monetary Fund).

Hemming, Richard, Selma Mahfouz, and Axel Schimmelpfennig, 2002, "Fiscal Policy and Economic Activity During Recessions in Advanced Economies," IMF Working Paper 02/87 (Washington: International Monetary Fund).

Hubbard R. Glenn, and Kenneth L. Judd, 1986, "Liquidity Constraints, Fiscal Policy, and Consumption," Brookings Papers on Economic Activity: I, Brookings Institution.

Hunt, Benjamin, and Douglas Laxton, "Some Simulation Properties of the Major Euroarea Economics in MULTIMOD," paper presented at the CEPR/ZEI conference on Empirical Models of the Euroeconomy Euroconference: Macro Performance, Bonn, June.

Ibrahim, Salifu B., and Francis Y. Kumar, 1996, "Comovements in Budget Deficits, Money, Interest Rates, Exchange Rates and the Current Account Balance: Some Empirical Evidence," Applied Economics, Vol. 28, pp.117-30.

International Monetary Fund, 1995a, World Economic Outlook, October 1995: A Study by the Staff of the International Monetary Fund, World Economic and Financial Surveys (Washington).

, 1995b, United States - Background Papers, IMF Staff Country Report No. 95/94 (Washington).

,1996a, World Economic Outlook, May 1996: A Study by the Staff of the International Monetary Fund, World Economic and Financial Surveys (Washington).

—, 1996b, Germany—Recent Economic Developments and Selected Issues, IMF Staff Country Report No. 96/111 (Washington).

—, 1997, Japan-Economic and Policy Developments, IMF Staff Country Report No. 97/91 (Washington).

—_, 1998, Japan-Selected Issues, IMF Background Paper No. 98/191 (Washington). ,2002a, United Kingdom-Selected Issues, IMF Background Paper (forthcoming). 
, 2002b, Japan-Selected Issues, IMF Background Paper (forthcoming).

Kandil, Magda, 1991, "Structural Differences between Developed and Developing Countries: Some Evidence and Implications," Economic Notes, Vol. 20, pp. 254-78.

Khalid, Ahmed M., 1996, "Ricardian Equivalence: Empirical Evidence from Developing Economies," Journal of Development Economics, Vol. 51 (December), pp. 413-32.

Khan, Mohsin S., and Malcolm D. Knight, 1981, "Stabilization Programs in Developing Countries," Staff Papers, International Monetary Fund, Vol. 28, pp.1-53.

Kneller, Richard, Michael Bleaney, and Norman Gemmell, 1998, "Growth, Public Policy and the Government Budget Constraint: Evidence from OECD Countries," University of Nottingham, Department of Economics Discussion Paper No. 98/14.

Koelln, Kenneth, Mark Rush, and Doug Waldo, 1996, "Do Government Policy Multipliers Decrease with Inflation?" Journal of Monetary Economics, Vol. 38 (December), pp. $495-505$.

Koray, Faik, and Pingfai Chan, 1991, "Government Spending and the Exchange Rate," Applied Economics, Vol. 23 (September), pp. 1551-58.

Kormendi, R.C., 1983, “Government Debt, Government Spending, and Private Sector Behaviour," American Economic Review, Vol. 73, pp. 994-1010.

Krugman, Paul R., and Maurice Obstfeld, 1997, International Economics: Theory and Policy, $4^{\text {th }}$ ed. (Reading, Massachusetts: Addison-Wesley).

Kuttner, Kenneth N., and Adam S. Posen, 2002, "Passive Savers and Fiscal Policy Effectiveness in Japan," paper presented at the conference of CEPR-CIRJE-NBER, "Issues in Fiscal Adjustment," Tokyo, December.

Landau, Daniel, 1986, "Government and Economic Growth in the Less Developed Countries: An Empirical Study for 1960-80,"Economic Development and Cultural Change, Vol. 35, pp. 35-75.

Lane, Phillip R., and Roberto Perotti, 1996, "Profitability, Fiscal Policy, and Exchange Rate Regimes," CEPR Discussion Paper No. 1449 (London: Centre for Economic Policy Research).

Lane, Timothy D., Atish Ghosh, Javier Hamann, Steven Phillips, Marianne Schulze-Ghattas, andTsidi Tsikata, 1999, IMF-Supported Programs in Indonesia, Korea, and Thailand; A Preliminary Assessment, IMF Occasional Paper No. 178 (Washington: International Monetary Fund). 
Laxton, Douglas, Peter Isard, Hamid Faruqee, Eswar Prasad, and Bart Turtelboom, 1998, MULTIMOD III: The Core Dynamic and Steady-State Models, IMF Occasional Paper No. 164 (Washington: International Monetary Fund).

Leiderman, Leonardo, and Mario I. Blejer, 1988, "Modeling and Testing Ricardian Equivalence: A Survey," Staff Papers, International Monetary Fund, Vol. 35 (March), pp. 1-35.

Lucas, Robert E., 1975, "An Equilibrium Model of the Business Cycle," Journal of Political Economy, Vol. 83, pp. 1113-44.

- 1988 , "On the Mechanics of Economic Development," Journal of Monetary Economics, Vol. 21, pp. 3--32.

—, and Nancy L. Stokey, 1983, "Optimal Fiscal and Monetary Policy in an Economy Without Capital," Journal of Monetary Economics, Vol. 12, No. 1, pp. 55-94.

Ludvigson, Sydney, 1996, “The Macroeconomic Effects of Government Debt in a Stochastic Growth Model," Journal of Monetary Economics, Vol. 38 (March), pp. 25-45.

Mankiw, Gregory N., 1985, "Small Menu Costs and Large Business Cycles: A Macro-economic Model of Monopoly," Quarterly Journal of Economics, Vol. 100, pp. 529-37.

,2000, "The Savers-Spenders Theory of Fiscal Policy," American Economic Review, Vol. 90 (May), pp. 120-25.

— Short-Term Interest Rates?" NBER Working Paper No. 1345 (Cambridge, Massachusetts: National Bureau of Economic Research).

Masson, Paul, Tamin Bayoumi, and Hossein Samiei, 1995, "Saving Behavior in Industrial and Developing Countries," in Staff Studies for the World Economic Outlook, World Economic and Financial Surveys (Washington: international Monetary Fund).

Matsuoka, Mikihiro, 1996, "Measuring the Effects of Fiscal Policy in Japan," (unpublished; Daiwa Institute).

McDermott, John C., and Robert F. Westcott, 1996, "An Empirical Analysis of Fiscal Adjustments," Staff Papers, International Monetary Fund, Vol. 43 (December), pp. 725-53. 
McKibbin, Warwick J., 1997, "Empirical Evidence on International Economic Policy Coordination," in Handbook of Macroeconomic Policy in Open Economies, ed. by Michele Fratianni, Dominick Salvatore, and Jurgen von Hagen (Westport, Connecticut, and London: Freenwood Press).

McMillin, W. Douglas, and Faik Koray, 1990, "Does Government Debt Affect the Exchange Rate? An Empirical Analysis of the U.S.-Canadian Exchange Rate," Journal of Economics and Business, Vol. 42, (November), pp. 279-88.

Melvin, Michael, Don Schlagenhauf, and Ayhan Talu, 1989, "U.S. Budget Deficit and the Foreign Exchange Value of the Dollar," Review of Economics and Statistics, Vol. 71 (August), pp. 500-05.

Miller, Marcus, Robert Skidelsky, and Paul Weller, 1990, "Fear of Deficit Financing-Is it Rational?" in Public Debt Management: Theory and History, ed. by Rudiger Dombusch and Mario Draghi (Cambridge and New York: Cambridge University Press), pp. 293-310.

Miller, Stephen M., and Frank S. Russek, 1989, "Are the Twin Deficits Really Related?" Contemporary Policy Issues, Vol. 7 (October), pp. 91-115.

Mountford, Andrew, and Harald Uhlig, 2002, "What are the Effects of Fiscal Policy Shocks?" CEPR Discussion Paper No. 3338 (London: Centre for Economic Policy Research).

Murphy, Kevin M., Andrei Shleifer, and Robert W. Vishny, 1989, "Industrialization and the Big Push," Journal of Political Economy, Vol. 97, pp. 1003-26.

Obstfeld, Maurice, 1998, "Comment on The Political Economy of Fiscal Adjustments," Brookings Papers on Economic Activity: 1, Brookings Institute, pp. 249-54.

Organization for Economic Cooperation and Development, 1996, "The Experience with Fiscal Consolidation in OECD Countries," Economic Outlook (June), pp. 33-41, (Paris: OECD).

—, 1999, "The Size and Role of Automatic Fiscal Stabilizers," Economic Outlook (December), pp. 137-50, (Paris: OECD).

Owoye, Oluwole, Akorlie A. Nyatepe-Coo, and Olugbenga A. Onafowora, 1995, "Another Look at the Evidence on the Efficacy of Monetary and Fiscal Policies in Developing Countries: An Application of the St. Louis Equation," Indian Economic Journal, Vol. 43, No. 1, pp. 127-39.

Parker, Jonathan, 1999, "The Response of Household Consumption to Predictable Changes in Social Security Taxes," American Economic Review, Vol. 89, No. 4, pp. 959-73. 
Perotti, Roberto, 1999, "Fiscal Policy When Things are Going Badly," Quarterly Journal of Economics (forthcoming).

,2002, "Estimating the Effects of Fiscal Policy in OECD Countries," paper presented at an ISOM conference, Frankfurt, June.

Perry, G. L., and C.L. Schultze, 1993, "Was this Recession Different? Are they all Different?" Brookings Papers on Economic Activity: 1, Brookings Institution, pp. $145-211$.

Plosser, Charles I., 1982, "Government Financing Decisions and Asset Returns," Journal of Monetary Economics, pp. 325-52.

Rama, Martin, 1993, "Empirical Investment Equations for Developing Countries," in Striving for Growth After Adjustment: The Role of Capital Formation, ed. by Luis Servén and Andrés Solimano (Washington: World Bank).

Ramey, Valerie A., and Matthew D. Shapiro, 1997, "Costly Capital Reallocation and the Effects of Government Spending," NBER Working Paper No. 6283 (Cambridge, Massachusetts: National Bureau of Economic Research).

Richardson, Pete, 1988, “The Structure and Simulation Properties of OECD's Interlink Model," OECD Economic Review, No. 10 (Spring), pp. 57-122.

Roeger, Werner, and Jan in't Veld, 2002, "Some Selected Simulation Experiments with the European Commission's QUEST Model," paper presented at the CEPR/ZEI conference on Empirical Models of the Euroeconomy Euroconference: Macro Performance, Bonn, June.

Romer, Christina D., and David H. Romer, 1994, "What Ends Recessions?" in NBER Macroeconomics Annual 1994, ed. by Olivier Blanchard and Stanley Fischer (Cambridge, Massachusetts: National Bureau of Economic Research).

Rosenzweig, Jeffrey A., and Ellis W. Tallman, 1993, "Fiscal Policy and Trade Adjustment: Are the Deficits Really Twins?” Economic Inquiry, Vol. 31, pp. 580-94.

Rotemberg, Julio J., and Michael Woodford, 1993, "Dynamic General Equilibrium Models with Imperfectly Competitive Product Markets," NBER Working Paper No. 4502 (Cambridge, Massachusetts: National Bureau of Economic Research).

Saito, Jun, 1997, "The Japanese Business Cycle after 1991: How is it Different, and Why?" Journal of Asian Economics, Vol. 8, pp. 263-93. 
Sargent, Thomas, and N. Wallace, 1975, "Rational Expectations, the Optimal Monetary Instrument, and the Optimal Money Supply Rule," Journal of Political Economy, Vol. 83, pp. 241-54.

Seater, John J., 1993, "Ricardian Equivalence," Journal of Economic Literature, Vol. 31, pp. 142-190.

____, and Roberto S. Mariano, 1985, "New Tests of the Life Cycle and Tax Discounting Hypothesis,' Journal of Monetary Economics, pp. 195-215.

Seidman, Laurence S., 2001, “Reviving Fiscal Policy,” Quest, Vol. 44, No. 3, pp. 17-42.

Shapiro, Matthew D., and Joel Slemrod, 1995, "Consumer Response to the Timing of Income: Evidence from a Change in Tax Withholding," American Economic Review, Vol. 85, No. 1, pp. 274-83.

Souleles, Nicholas S., 1999, "The Response of Household Consumption to Income Tax Refunds," American Economic Review, Vol. 89, No. 4, pp.947-58.

Sutherland, Alan, 1997, "Fiscal Crises and Aggregate Demand: Can High Public Debt Reverse the Effects of Fiscal Policy?" Journal of Public Economics, Vol. 65 (August), pp.147-62.

Tanzi, Vito, 1986, "Fiscal Policy Responses to Exogenous Shocks in Developing Countries," American Economic Review, Vol. 76, pp. 88-91.

_- and Mark S. Lutz, 1993, "Interest Rates and Government Debt: Are the Linkages Global Rather than National," in The Political Economy of Government Debt, ed. by H.A.A. Verbon and F.A.A.M. Van Winden (Amsterdam, New York: North Holland).

Taylor, John, 1979, "Staggered Price Setting in a Macro Model," American Economic Review, Vol. 69, pp. 108-13.

Throop, Adrian W., 1989, "Fiscal Policy, the Dollar, and International Trade: A Synthesis of Two Views," Federal Reserve Bank of San Francisco Economic Review (Summer), pp. $27-44$.

van Aarle, Bas, Harry Garrestsen, and Niko Gobbin, 2001, "Monetary and Fiscal Policy Transmission in the Euroarea: Evidence from a Structural VAR Analysis," paper presented at a Vienna Institute for International Economic Studies seminar, Vienna, January.

von Hagen, Jürgen, Andrew Hughes-Hallett, and Rolf Strauch, 2001, "Budgetary Consolidation in EMU," CEPR Discussion Paper No. 148 (London: Centre for Economic Policy Research). 
Weber, Christian E., 1999, "Fiscal Policy in General Equilibrium: Empirical Estimates from an Error Correction Model," Applied Economies, Vol. 31 (July), pp. 907-13.

Zarnowitz, Victor, 1999, "Theory and History Behind Business Cycles: Are the 1990s the Onset of a Golden Age?" NBER Working Paper No. 7010 (Cambridge, Massachusetts: National Bureau of Economic Research). 